\title{
Modeling and Analysis
}

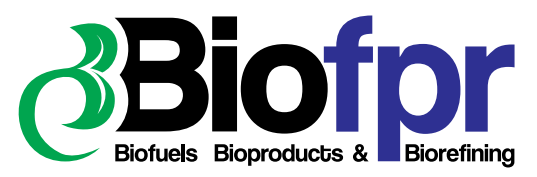

\section{Achieving negative emissions in plastics life cycles through the conversion of biomass feedstock}

Camilla C N de Oliveira (D, Marianne Z Zotin (1), Pedro R R Rochedo (1), Alexandre Szklo (i), Centre for Energy and Environmental Economics (CENERGIA), Energy Planning Program (PPE), Graduate School of Engineering (COPPE), Universidade Federal do Rio de Janeiro (UFRJ), Centro de Tecnologia, Bloco C, Sala 211 Cidade Universitária, Ilha do Fundão, Rio de Janeiro, Brazil

Received April 05 2020; Revised October 01 2020; Accepted October 07 2020; View online at Wiley Online Library (wileyonlinelibrary.com); DOI: 10.1002/bbb.2165; Biofuels. Bioprod. Bioref. (2020)

Abstract: Plastics are one of the fastest-growing groups of bulk materials in the world. Yet, a third of plastic waste ends up as terrestrial or marine pollution. As a strategy to lower the carbon footprint of plastics, this study aimed to test the hypothesis that using plastics in long-term applications would bring an environmental advantage due to the reduction of plastic pollution, the achievement of negative $\mathrm{CO}_{2}$ emissions (NETs) by bio-based plastics, and demand reduction for emission-intensive construction materials, such as iron, aluminium, wood, and cement. Cradle-to-grave life cycle greenhouse gas (GHG) emissions of high-density polyethylene (HDPE), polyvinyl chloride (PVC), polyethylene terephthalate (PET), and expanded polystyrene (EPS) were performed for four ethylene production routes. For the final disposal, this study assessed incineration; incineration with energy recovery; recycling; and the orientation of plastics for replacing emission-intensive material construction (longterm applications). Findings show that using plastics as long-lifetime materials could lead to NETs, particularly in the cases of bio-based HDPE, bio-based PET, and bio-based EPS. Hence, an opportunity arises, by producing plastics for long-term applications, to reduce both the carbon footprint and the plastic waste generation that may enter the marine environment. (C) 2020 Society of Industrial Chemistry and John Wiley \& Sons Ltd

Supporting information may be found in the online version of this article.

Key words: Plastics; BIOCCUS; Sugarcane; Carbon footprint

\section{Introduction}

$D$ lastics are one of the largest groups of chemical products and the fastest growing group of bulk materials in the world, ${ }^{1,2}$ apart from cement and steel. ${ }^{3,4}$ Their unrivaled features include durability, light weight, high strength-to-weight ratio, hardness, ease of design and manufacture, and low cost. ${ }^{5,6}$ However, the durability of plastics has led to a controversial debate in the society. ${ }^{7,8}$ On one hand, their low degradability, non-toxicity, and water, chemical, and decay resistance can be advantageous as an alternative to traditional materials such as glass, metal, or

Correspondence to: Camilla C. N. de Oliveira, Centre for Energy and Environmental Economics (CENERGIA), Energy Planning

Program (PPE), Graduate School of Engineering (COPPE), Universidade Federal do Rio de Janeiro (UFRJ), Centro de

Tecnologia, Bloco C, Sala 211 Cidade Universitária, Ilha do Fund\&atilde;o, Rio de Janeiro, RJ 21941-972, Brazil.

E-mail: camillacnoliveira@gmail.com 
wood. In addition, the low degradability of plastics increases their lifetime if they are applied in long-term applications. On the other hand, as plastic waste is still mismanaged, around $60 \%$ of the plastics produced from 1950 to 2015 ends up as terrestrial or marine pollution, accounting for 4900 million metric tons of plastic waste. ${ }^{2}$ The report 'The marine plastic footprint' 131 estimates that 12 million metric tonnes of plastics leak to the marine environment every year.

Plastic and microplastic pollution have negative effects on the marine environment and on its food chain, including human beings. ${ }^{9}$ Microplastics contaminate tap and bottled water, which leads to possible effects on human health. ${ }^{10,11}$ There are over 150 million tonnes of plastic waste in the ocean today, ${ }^{9,12,13}$ and in 2050 there will be more plastics, by weight, than fish in the ocean, unless action is taken. ${ }^{10,13}$ Single-use plastics such as grocery bags, food packaging, bottles, straws, containers, cups and cutlery are the greatest contributors to this leakage. . $^{13,14}$

Complete elimination of post-consumer plastics bets on destructive thermal treatment such as combustion or pyrolysis. ${ }^{15}$ Despite addressing the accumulation of plastic waste that may end in the marine environment, these solutions contribute to further increase greenhouse gas (GHG) emissions, even if the energy embodied in the plastic is partially recovered. Besides environmental pollution, the upstream of the plastic industry (petrochemical industry) is one of the key 'blind spots' in the global energy debate because many of its fossil hydrocarbons enter the sector as feedstock and do not undergo combustion. The sector, thus, achieves the contradictory feat of being the largest industrial fossil fuel user, accounting for $28 \%$ of the global industrial final energy consumption ${ }^{1,16}$ and yet it is only the third-largest industrial $\mathrm{CO}_{2}$ emitter, representing $18 \%$ of all industrial $\mathrm{CO}_{2}$ emission. ${ }^{1}$

For this reason, the sector needs a holistic strategy to both reduce GHG emissions in energy and material flows and stop plastic pollution, especially in marine environments. Bio-based materials, the circular economy, and product innovations are expected to play a critical role in decarbonizing the chemical sector while harnessing the many benefits of plastics. ${ }^{13,17-19}$

Zheng and $\mathrm{Suh}^{20}$ evaluate four strategies to reduce the carbon footprint of plastics in global scale: $100 \%$ sugarcane and corn-based plastics, $100 \%$ renewable energy, $100 \%$ recycling, and halving plastic growth in demand. According to them, for the lowest GHG mitigation potential to happen (93\% GHG reduction from the baseline in 2050), the four strategies should be implemented in concert. However, the study lacks the evaluation of a fifth option: orient plastics production through the conversion of biomass feedstock towards long-lifetime products as a strategy to achieve negative emissions.

Spierling et al. ${ }^{19}$ estimated that bio-based plastic could save 241 to $316 \mathrm{MtCO}_{2 \text { eq }}$ per year by substituting $65.8 \%$ of all conventional plastics. Bio-based plastics can act as a negative emission technology (NET) depending on the plastic's final disposal. ${ }^{18}$ (NET are defined by the 2018 IPCC special report. ${ }^{21}$ Other technologies considered NETs are afforestation, soil carbon sequestration, direct air capture with storage (DAC-S) and bioenergy with carbon capture and storage (BECCS)). ${ }^{22}$ Actually, NETs have been widely selected by integrated assessment models (IAM) to meet the requirements of temperature limits of $1.5^{\circ} \mathrm{C} .{ }^{23-25}$ Nonetheless, the scientific literature on IAMs still lacks evaluating NETs through the conversion of biomass into chemical products. ${ }^{18}$ Exceptions are Daioglou et al. ${ }^{26-28}$ which include in their modeling exercise the demand from the non-energy sector, although in an aggregate manner, for basic petrochemicals; and Lap et al. ${ }^{29}$ who explored in an IAM the biomass competition between energy and chemicals, however, the analysis was restricted to a few petrochemicals and leaves the competition between energy and food out of the scope. We therefore aim to fill this gap, understanding that, if used in long-term applications, bioplastics could be capable of removing atmospheric GHG, which we call here BIOCCUS (biomass with carbon capture utilization and storage).

After packaging, the construction industry is already the second largest consumer of plastics, accounting for $16 \%$ of global consumption, ${ }^{1,15}$ polyvinyl chloride (PVC) being the plastic that is adopted most, especially for pipes, windows, and door frames. ${ }^{1}$ The use of plastic in long-term application, such as construction, delay their end-of-life emissions by around 35 years ${ }^{15}$ nowadays, depending on the application. However, as plastic's low degradability could enable carbon storage for thousands of years, 35 years of carbon storage in buildings is only the worst-case scenario. Bio-based plastic infrastructure could therefore act as a long-term NET, ${ }^{18,30}$ if strong regulatory measures are taken to certificate this longterm use. (Long-term material application in the construction or infrastructure sectors have a useful lifetime of around 35 years. ${ }^{2}$ ) It is also easier to permanently dispose the plastics concentrated in one use (construction), in scale and location, than in a dispersed manner as occurs with single-use plastics. As a mitigation strategy, plastics could compete in specific applications with energy-intensive construction materials, such as cement and steel, rediscovering a historical strategy of the industry to expand markets by substituting traditional materials as an approach to adapting to climate emergency imperatives. Several countries have already banned single- 
use plastics; ${ }^{31}$ if this trend persists it will naturally pressure the plastics industry to search for new markets. In addition, by substituting traditional construction materials, it reduces deforestation caused by their mining. ${ }^{30}$

Despite the literature presenting reviews of plastic life-cycle assessment ${ }^{32-36}$ (LCA), there is a lack of studies investigating how the end use of plastic affects LCA. The use of plastics for long-term applications, such as construction, can reduce GHG emissions during their lifetime, as this application stores the plastic (and the carbon in its molecular structure) for decades, delaying their final disposal. Although the same may occur in single-use applications, long-term applications avoid both emissions from recycling or incineration and potential marine pollution due to plastic mismanagement. If bio-based plastics are considered, the biogenic carbon absorbed during biomass cultivation and then captured in plastics could also result in negative emissions. ${ }^{18}$ Given the urgency of dealing with plastic waste and to decarbonize the petrochemical industry, this paper investigates which plastics' final disposal option achieves the lowest carbon footprint or even negative emissions. The hypothesis tested is that orienting plastic production to the construction sector, instead of applications that require extensive recycling or incineration, such as packaging, would result in an environmental advantage for three reasons: the biogenic carbon embodied in the plastic would be stored in a long-lifetime material; ${ }^{18}$ if plastic waste is used for construction purposes, it would reduce plastic waste accumulation, ${ }^{37}$ delaying for decades its final disposal and related emissions, and it would reduce the demand for emission-intensive construction materials such as cement, aluminium, steel, and wood from deforestation.

The increase in the usage of plastics in construction does not automatically lead to a reduction in plastic packaging. However, the drop of plastic use in packaging is already happening and several countries have been banning singleuse plastics. ${ }^{14}$ On the other hand, the use of plastic in construction has been increasing since the emergence of plastic in $1950 .{ }^{15}$ We therefore considered in our study that the use of plastics in construction could be an alternative to compensate the packaging market loss, which should be accelerated by more stringent environmental policies. In other words, we considered a twin objective by both promoting the usage of plastics in construction and accelerating the market loss in package. Actually, this is already happening in the two major Brazilian cities. ${ }^{38,39}$

The next section of this article shows the landscape of waste plastic. Then, the paper describes the methodology applied to assess the carbon footprint of the plastics selected according to their final disposal. Finally, we present the results and discussion of this assessment.

\section{Landscape of plastic waste}

The global plastics production was around $2 \mathrm{Mt}^{15}$ in 1950 and has increased 200 times since then. ${ }^{13,40}$ In 2016, the global production of plastics reached $396 \mathrm{Mt}$, emitting $2 \mathrm{Gt}$ of $\mathrm{CO}_{2}$, representing around $6 \%$ of total global $\mathrm{CO}_{2}$ emissions per year. ${ }^{40}$ The global plastic capacity has increased $4 \%$ per year since $20000^{40}$ Should this trend continue, plastic production is expected to increase by $40 \%$ until $2030^{40}$ when compared to 2000.

According to UN Environment's global mapping, ${ }^{41}$ China leads plastic production and consumption, followed by North America and Western Europe, with 28\%, 19\%, and $19 \%$, respectively for production and $20 \%, 21 \%$ and $18 \%$, respectively for consumption.

Polypropylene (PP), low-density polyethylene / linear low-density polyethylene (LDPE/LLDPE), polyvinyl chloride (PVC), high-density polyethylene (HDPE), polyethylene terephthalate (PET), and polystyrene (PS) are the most used plastic polymers in the world ${ }^{2,41}$ which cover $21 \%, 20 \%$, $11.8 \%, 16.3 \%, 10.2 \%, 7.6 \%$, respectively. Figure 1 shows historical global primary plastics production per polymer type.

Packaging is the main application for plastic followed by construction, accounting for $36 \%$ and $16 \%$, respectively, of total plastic usage in 2017. ${ }^{1,15}$ Figure 2 shows the consumption of plastics by end-use sector.

Geyer et al..$^{15}$ estimated that, in 2015, $407 \mathrm{Mt}$ of virgin plastics entered the use phase and $302 \mathrm{Mt}$ left it as waste. The products' lifetimes rely on polymer type and industrial use, as shown in Fig. 3. For instance, plastics for construction leave the use phase decades later than packaging plastics, which present a lifetime of 1 year maximum. ${ }^{15}$

In the end of their lifetime, the plastics waste follows three main trajectories: ${ }^{15}$ recycling, which delays their final disposal; incineration, which destroys them thermally with or without energy recovery; and landfilling, when they are discarded in a sanitary landfill. Due to plastic waste mismanagement, open dumps and the natural environment are both current final disposal options for plastics. ${ }^{42}$ Recycling is also considered for $n$ recycles loops. After that, the plastic is sent to any of the final disposal options left. As mentioned before, this study does not analyze the disposal of plastics in landfills.

\section{Recycling}

Recycling is the backbone of circular the economy ${ }^{43}$ and an 'essential tool out of a whole toolbox to better manage natural resources. ${ }^{34}$ Nonetheless, recycling a plastic can lead to a down 


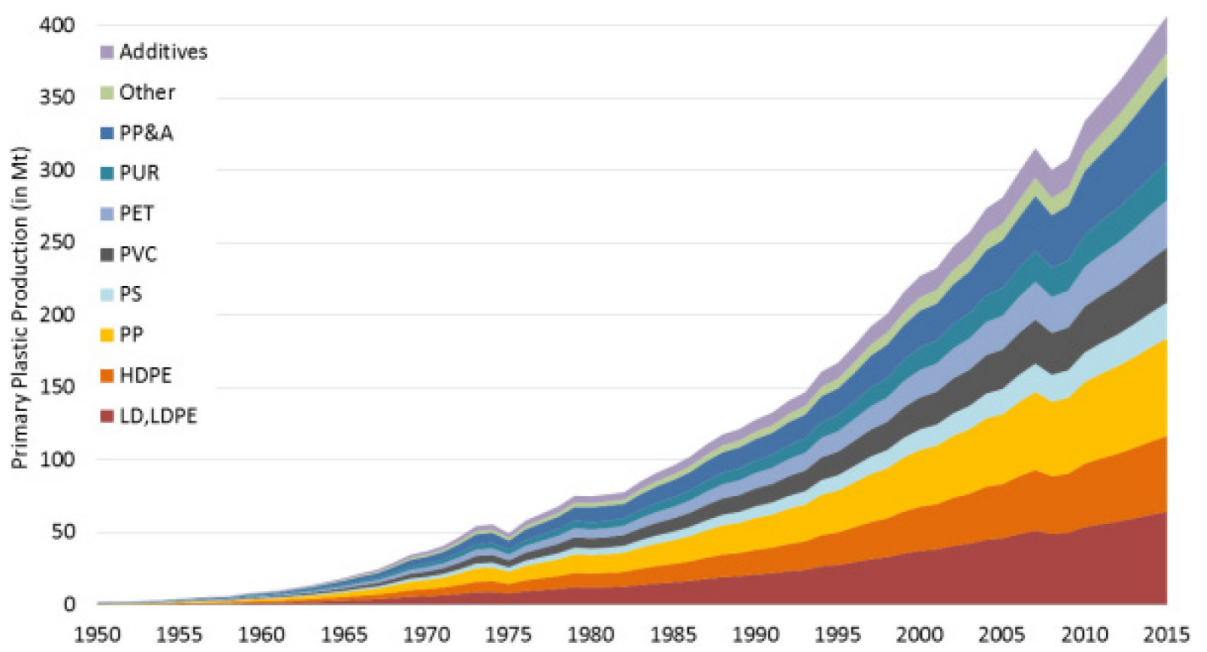

Figure 1. Global primary plastics production according to polymer type from 1950 to 2015. LD, LDPE = Low-density and linear low-density polyethylene; HDPE = High-density polyethylene; PP = polypropylene; PS = polystyrene;

PVS = polyvinylchloride; $\mathrm{PET}=$ polyethylene terephthalate; $\mathrm{PUR}=$ polyurethanes; $\mathrm{PP} \& \mathrm{~A}=$ polyester, polyamide, and acrylic . Source: Geyer et al. ${ }^{15}$

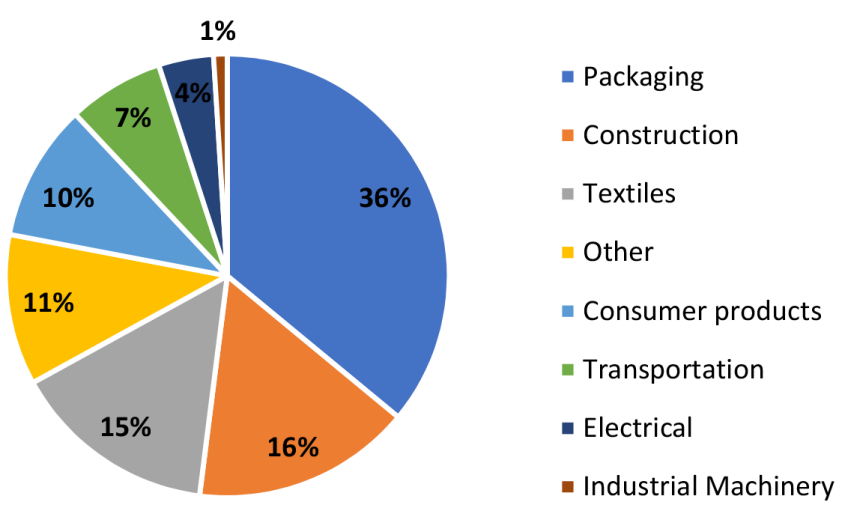

Figure 2. Estimated consumption of plastic by end-use sector. Source: Based on Geyer et al. ${ }^{15}$ and IEA ${ }^{1}$

cycle process, in which the plastic returns to the cycle with a lower quality. ${ }^{45}$ The quality of recycling plastic therefore needs to be improved and the plastic's properties should be maintained to increase the 'circularity' of plastics. ${ }^{47,48}$

The average recycling rate in the $\mathrm{EU}$ is $30 \%,{ }^{49,50}$ whereas in developing countries it is around $20-40 \%,{ }^{49}$ with exception of India whose recycling rate is around $60 \%{ }^{51}$ In the USA only $9.1 \%$ of plastics were recycled in $2015^{52}$ and the recycling rates in low-to-middle-income countries are largely unknown. ${ }^{49}$ Despite the higher recycling rate of high-income countries, most of the so-called recyclables plastic waste is being shipped abroad and dumped in local communities in low and middle-income countries, especially in South East Asia. ${ }^{53}$ This phenomenon is being seen as 'the recycling myth. $^{53}$
In 2018, China banned the imports of recyclable plastics in order to improve quality of life. ${ }^{54}$ Until then, the country imported up to $56 \%$ of the world's plastic garbage to recycle. ${ }^{55}$ This decision has engendered a new stage in the world recycling industry, ${ }^{40,49,53}$ in which exporters nations have to find alternatives to get rid of their plastic waste, such as recycling. In 2020, China also decided to ban non-degradable bags in major cities by the end of 2020 and in the whole country in $2022 .{ }^{56}$

According to Geyer et al. ${ }^{15}$ plastic waste totaled $6300 \mathrm{Mt}$ between 1950 and 2015. Of this, $9 \%$ was recycled ${ }^{11,13}$ and only $10 \%$ of this was recycled more than once. ${ }^{13}$ Recycling delays final disposal, rather than avoiding it, ${ }^{15}$ because most of the plastics are recycled into lower value applications that are not recycled again after use. ${ }^{13}$

Plastic waste is a complex material mixture comprising a large group of individual polymers with different chemical and technical characteristics that hinder the recycling process. ${ }^{57-59}$ Moreover, post-consumer plastics contain organic and inorganic substances as contaminants that lead to a recycled plastic with poor material properties, ${ }^{59}$ which, in turn, limits the applicability of the recycled plastic. Organic contaminants may degrade or migrate during recycling, while inorganic substances such as metal impurities and residues from catalysts may persist in the product after the recycling process. $^{59}$

There are two main types of plastic recycling: mechanical (primary and secondary) and chemical (tertiary). ${ }^{7,57,60}$ The choice among both recycling methods depends on the degree of contamination of the plastics with organic or inorganic 


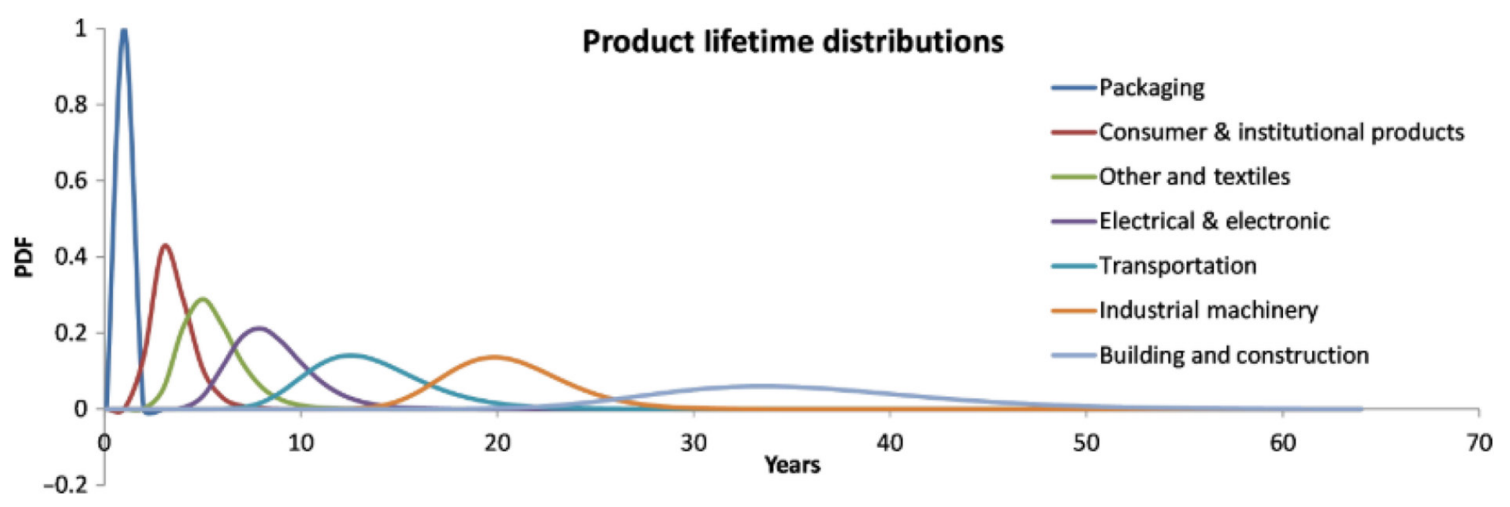

Figure 3. Product lifetime distributions for eight industrial use sectors plotted as lognormal probability distribution functions (PDF). Source: Geyer et al. ${ }^{15}$

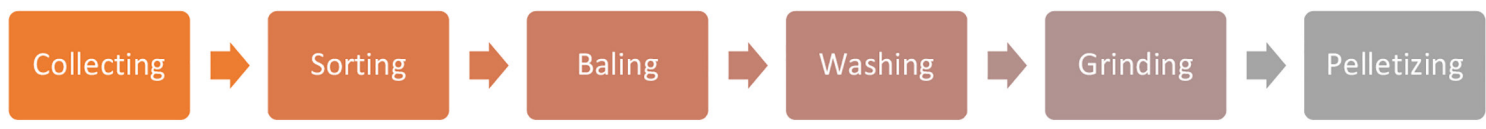

Figure 4. Steps of secondary mechanical recycling. Source: Based on Ragaert et al. ${ }^{57}$

substances and also on the molecular structure of the plastic. ${ }^{60}$ First, mechanical recycling is the most established method due to its low cost and high reliability, ${ }^{7,857,60}$ keeping the polymer's structure basically intact. ${ }^{60}$ If the source of plastic waste is pre-consumer, and therefore clean and without contamination, the primary mechanical recycling is used. Post-consumer plastic waste is highly contaminated and requires additional steps like collecting, sorting and cleaning. ${ }^{57,60}$ Figure 4 shows the steps included in the secondary mechanical recycling. After the plastic waste is collected, it is sorted based on size, color, density and chemical composition and then it is baled for transport purposes. To remove the contaminants, the product is washed and then it passes through grinding and pelletizing to be transformed, finally, into raw materials for new plastics. ${ }^{57}$

The recyclability of plastics is determined by the design of the product and the degree to which it can incorporate recycled materials. ${ }^{57}$ 'Design for recycling' is heavily promoted by the EU within the concept of the circular economy as a strategy to ensure that the products developed will be recycled at the end of their life. ${ }^{61}$ For the recyclability purpose, the plastic should 'maintain its mechanical and chemical properties ${ }^{\text {'44 }}$ and 'be able to be sorted by recycling companies $^{24}$ in an acceptable cost-to-performance ratio. ${ }^{44}$

Some plastics are more recycled than others. To assist their sorting prior to recycling, the resins present on the bottom of plastic packaging an identification code ranging from 01 to 07 in the following order: ${ }^{1}$ polyethylene terephthalate (PET), high-density polyethylene (HDPE), polyvinyl chloride
(PVC), low-density polyethylene (LDPE), polypropylene $(\mathrm{PP})$, polystyrene $(\mathrm{PS})$, and others $(\mathrm{O})$, which include polycarbonate, acrylonitrile butadiene styrene, styrene acrylonitrile, polymethyl methacrylate, polyacrylonitrile, polyvinyl acetate, and many others.

Unlike mechanical recycling, chemical recycling enables the petrochemical components in plastics to be recovered. It means that the polymers are chemically converted to monomers through a chemical reaction in the presence of a catalyst. ${ }^{62}$ This process enables new polymerizations with the resulting monomers reproducing the original polymer or a related polymeric product. ${ }^{57}$ Despite the advantage in achieving the quality of virgin polymers ${ }^{44}$ chemical recycling has higher costs than mechanical recycling and requires a large scale to become economically feasible. ${ }^{44,57}$ Currently, this process is economically reasonable for polymers such as polyethylene terephthalate (PET), polymethyl methacrylate (PMMA), and polyether ether ketone (PEEK). ${ }^{44,57,60}$ However, as this is an energy-intensive but emerging method, we will only consider mechanical recycling in our assessment.

\section{Incineration}

If plastic waste presents a high degree of contamination, incineration is an option for the final disposal of plastic. ${ }^{63}$ The main advantages of incineration processes are the reduced need for landfill disposal, and the possibility of recovering energy to produce heat and electricity. ${ }^{36,64}$ The drawback of this method is the release of $\mathrm{CO}_{2}$ to the atmosphere 
when plastics are burned. ${ }^{65}$ In poor countries, too, plastic waste is incinerated in open fields for cooking or heat, ${ }^{66}$ exposing people to toxic and carcinogenic emissions such as chlorinated and brominated dioxins and furans for plastics containing chlorinated and brominated additives. ${ }^{14,67}$ Even in developed countries with emission control plants, there is a risk of exceeding the limit value for toxic emissions. Measurements in an incinerating plant in Norway have revealed that the emissions of dioxins, furans and other toxic pollutants were far beyond the limits set by the European laws. ${ }^{68}$ According to Hamilton et al., ${ }^{69}$ in 2019 , the production and incineration of plastics will emit $850 \mathrm{Mt}$ of GHG, equal to the emissions from 189 coal power plants. If the trend in plastic production and incineration continues, it is estimated that, in 2050, plastic alone could consume $10-13 \%$ of the total remaining carbon budget, undermining efforts to keep warming below $1.5^{\circ} \mathrm{C} .{ }^{69}$

\section{Long-lifetime plastics}

Plastic applications in construction usually lead to energy savings due to better insulation. ${ }^{70}$ Plastics usually presents ductility, advantages in terms of thermal properties, resistance to chemical attack, electric insulation properties, and light weight. ${ }^{71-73}$ Plastics in construction also reduce total costs, are easy to install and require minimal maintenance. ${ }^{74}$ Substituting traditional materials with lightweight plastic can result in an indirect GHG emissions reduction in transportation. ${ }^{75}$ Hence, the long-term applications of plastics in the construction sector could be an interesting solution to reduce waste generation of materials such as cement and steel. (Substituting aluminium could perhaps reduce GHG emissions, but certainly not waste generation as aluminium has recycling rates around $98.00 \%$ in Brazil. $)^{76}$ For instance, the Dutch PlasticRoad concept consists of a prefabricated and modular road structure based on recycled plastics. ${ }^{77}$ The expected lifetime of the PlasticRoad is two to three times longer than that of traditional road paving and the expected construction time would be reduced by $70 \%{ }^{77}$ Due to its longer lifespan and the reduction of transport involved in its construction, PlasticRoad also presents a smaller carbon footprint than traditional road structures. ${ }^{77}$ Table 1 presents examples of plastic use in construction and building.

Several studies ${ }^{37,78-80}$ have shown the applicability of waste plastic in the construction industry for cementitiousbased materials. In this case, recycled plastics are reused to substitute virgin materials in infrastructures. This scheme is advantageous because it reduces the concrete density, increases concrete's toughness behavior, improves concrete's abrasion resistance, and increases concrete's thermal insulation properties. ${ }^{80}$ In 2011 , several companies developed eco-plastic bricks that exceeded the performance of concrete walls when used in emergency rooms. ${ }^{70}$

\section{Methods}

To test this hypothesis, this study assessed the carbon footprint of plastics. The case study was assessed for Brazil, as the country is a world leader in ethanol production, together with the USA, ${ }^{81}$ presenting one of the lowest ethanol production costs $(\$ 0.16-0.22 / 1) .{ }^{82}$ Brazil is also one of the world's major agricultural producers, ${ }^{83}$ and could become a competitive producer of bio-based plastics under stringent scenarios for GHG mitigation. ${ }^{18}$

This study focused on polymers derived from ethylene, as it is by far the most important building block in the petrochemical industry, ${ }^{84}$ and these polymers are the most commonly used plastic polymer in the world with applicability in the construction sector. The plastics studied

\section{Table 1. Examples of plastic use in the construction industry.}

\begin{tabular}{ll}
$\begin{array}{l}\text { Use } \\
\text { Façade panels }\end{array}$ & $\begin{array}{l}\text { Plastic } \\
\text { Sandwich panels covering with PVC, plasticized plates and polyurethane foams; }\end{array}$ \\
\hline Exterior covering & $\begin{array}{l}\text { Polyester coated concrete by molding from an existing plate; epoxy resins and polyesters on various } \\
\text { supporting media }\end{array}$ \\
\hline Weather boarding & Polyester; PVC; Polymethyl methacrylate \\
\hline Windows & PVC casing on metal molding; PVC/ wood; polyester glass fiber and phenolic foam core \\
\hline Wall lining & Coating - Polyvinyl acetate; sprayed lining polyurethane; wall tiles - Polystyrene; polyethylene \\
\hline Roof covering & Flat or corrugated sheets - Polyester, PVC, polymethylmethacrylate; gutters - Rigid PVC polyester \\
\hline Sanitary equipment & $\begin{array}{l}\text { Sinks - Polymethylmethacrylate, polyester, polyamides; Pipeworks - PVC; showers - Polymethylmethacrylate, } \\
\text { polyester, polyethylene }\end{array}$ \\
\hline Insulation & Polystyrene; PVC; polyurethane \\
\hline Damp-proofing & Polyethylene \\
\hline Based on The Constructor & \\
\hline
\end{tabular}


are high-density polyethylene (HDPE), polyvinyl chloride (PVC), polyethylene terephthalate (PET) and expanded polystyrene (EPS), constituting $16.3 \%, 11.8 \%, 10.2 \%$, and $7.6 \%$ of the world's production, respectively. ${ }^{2}$ Low-density polyethylene (LDPE) and linear low-density polyethylene (LLDPE) were not selected for the case study since their use as long-life time plastic (construction sector) is low $(5.5 \%)^{15}$ when compared to HDPE (20.2\%). ${ }^{15}$

Greenhouse gas emissions from ethylene production and from intermediate products, polymerization, and transformation into final products, transportation and final disposal were measured for each plastic. For the first plastic production step, four ethylene production routes were used as described in our previous study: ${ }^{18}$ conventional steam cracking of naphtha; sugar-cane-derived ethanol to ethylene without bio-energy with carbon capture and storage (BECCS); sugar-cane-derived ethanol to ethylene with BECCS; and bio-methanol to olefin. For final disposal, incineration, incineration with energy recovery (plastic-to-energy, P2E), and recycling were considered. The use of plastic for longterm applications (construction and infrastructure) as a method of final disposal was assessed, and the substitution of emission-intensive material construction (cement, aluminium, steel, wood, from eucalyptus planted forest and wood associated with deforestation in the Amazon) by a plastic material.

Landfilling is the main global final disposal for plastic packaging, followed by leakage to the environment, recycling and incineration, accounting for $40 \%, 32 \%, 14 \%$, and $14 \%$ in 2015 , respectively. ${ }^{14}$ Nonetheless, landfilling was not considered in this study because it was the least preferred option for waste management ${ }^{86}$ and it was not encouraged by policy. ${ }^{36}$ Uncontrolled release of methane, soil and ground water contamination by leachate, unpleasant odors and spread of pathogenic microorganisms are some of the waste landfilling's drawbacks. ${ }^{85}$ Despite recent efforts, ${ }^{87}$ the LCA method still faces several challenges when assessing the impacts of plastic mismanagement resulting in potential plastic pollution in the ocean environment.

The carbon footprints of HDPE, PVC, PET, and EPS were assessed from cradle to grave using a mass-based allocation method based on the principles given in ISO 14067:2018. ${ }^{88}$ Greenhouse gas emissions data were collected for the following life-cycle stages: production of ethylene, production of intermediate products, polymerization, transportation, transformation, and final disposal. Production of ethylene were used according to Oliveira et al.: ${ }^{18}$ conventional steam cracking of naphtha; sugar-cane-derived ethanol to ethylene without bio-energy with carbon capture and storage (BECCS); sugar-cane-derived ethanol to ethylene with
BECCS; and bio-methanol to olefin. Transportation in all cases is assumed to be made by truck for a distance of $100 \mathrm{~km}$. The specific consumption of diesel is $0.020 \mathrm{~L} \mathrm{t.km}^{-189}$ and the emission factor for diesel combustion is $75.243 \mathrm{~kg} \mathrm{CO}_{2}$ eq/ TJ..$^{90}$ The steps of production of each plastic are described below, starting with those that were common to all: ethylene production and final disposal options. Then, each plastic production will be described separately.

\section{Ethylene production}

Greenhouse gas emissions from each ethylene production route were based on Oliveira et al. (2019) ${ }^{18}$ as shown in Table 2. Ethylene's emission factors were assumed for Brazil. ${ }^{18,91,92}$

Conversions from ethylene and other inputs to intermediate products and to polymers were calculated by mass as shown in Fig. 5.

\section{Final disposal and material substitution}

The basic options considered for final disposal in this study include: (i) incineration; (ii) mechanical recycling; and (iii) application in the construction and infrastructure sector (C\&IF).

Incineration can occur with or without energy recovery (plastic-to-energy, P2E). All carbon stored in HDPE, PVC, PET, and PS was assumed to be released as $\mathrm{CO}_{2}$ in the incineration process. The repeating unit of HDPE is ethylene $\left(\mathrm{C}_{2} \mathrm{H}_{4}\right)$ whose molar mass is $28 \mathrm{gmol} \mathrm{g}^{-1}$. Stoichiometrically, if burned, one molecule of ethylene emits two molecules of $\mathrm{CO}_{2}$, i.e., $3.14 \mathrm{~g} \mathrm{CO}_{2} / \mathrm{g}$ ethylene $(2 \times 44 / 28)$. By analogy, it was calculated $\mathrm{CO}_{2}$ emissions for each type of plastic when incinerated, according to Table 3 .

Plastic-to-energy (P2E) is considered when the incineration process recovers energy from the plastic burning in a cogeneration plant (CHP) and uses it to produce electricity. The heat produced by each plastic is accounted for by their respective lower heating value (LHV). The incinerator electricity generation efficiency was assumed to be $23 \%{ }^{35}$ The Brazilian grid emission factor is used to estimate the avoided

\section{Table 2. GHG emissions for ethylene routes.}

\begin{tabular}{lc} 
Ethylene route & $\begin{array}{c}\text { Emission factor } \\
\text { (t CO } 2 \text { eq/ } t \text { ethylene) }\end{array}$ \\
Naphtha steam cracking & 1.02 \\
\hline Ethanol to ethylene w/ BECCS & 0.16 \\
\hline Ethanol to ethylene w/o BECCS & -0.41 \\
\hline Bio-methanol to olefins & 0.41 \\
\hline Oliveira et al. ${ }^{18}$ &
\end{tabular}




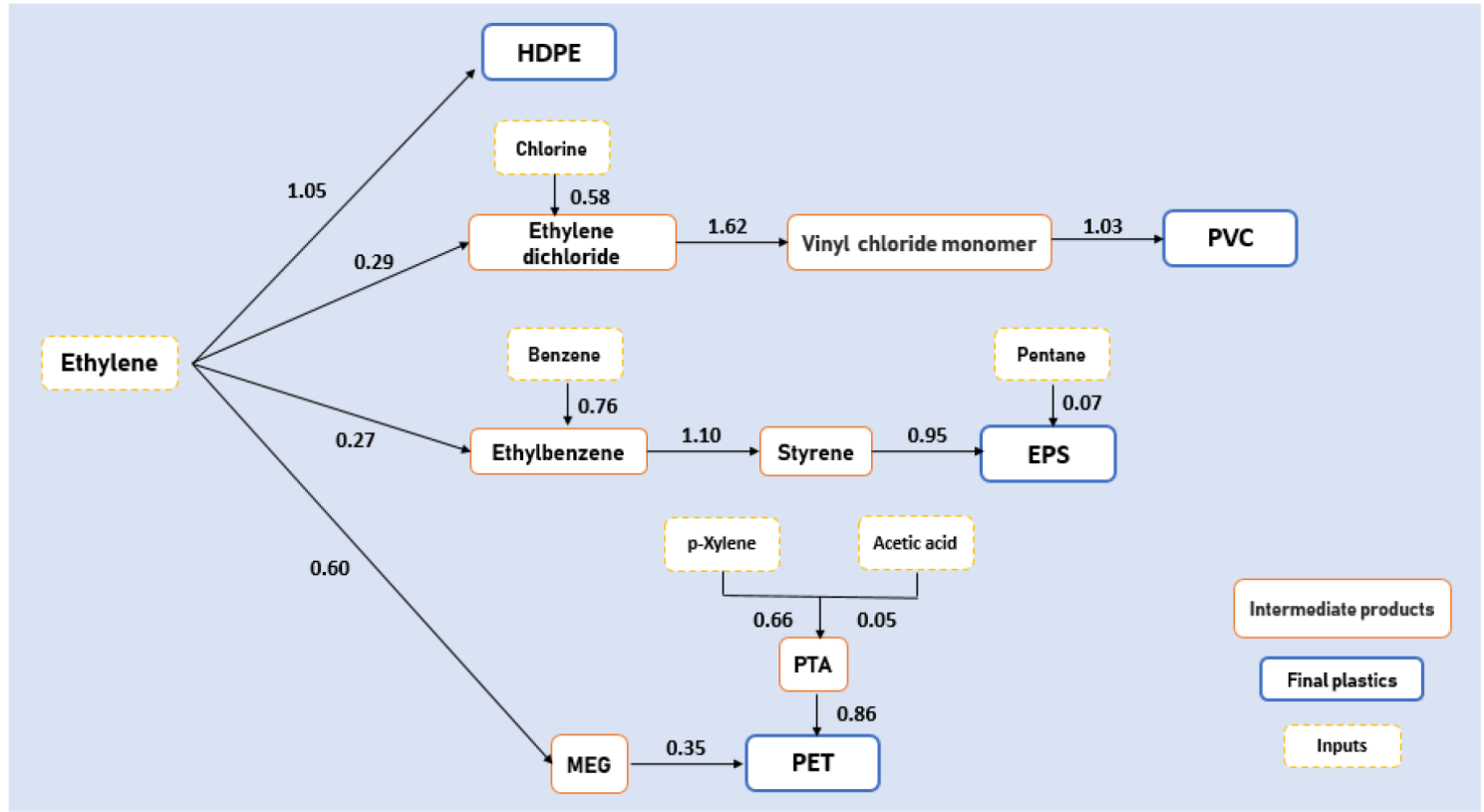

Figure 5. Mass conversions in tonnes of feedstock per tonne of product considered for HDPE, PVC, PET, and EPS production. Source: Based on Platts ${ }^{93}$ and Boulamanti and Moya. ${ }^{94}$

\section{Table 3. Incineration emission factors, LHV and electricity generated for HDPE, PVC, PET, and EPS.}

\begin{tabular}{lcccccc} 
Plastic & $\begin{array}{c}\text { Repeating unit } \\
\text { (molar mass in } \\
\text { gmol/g) }\end{array}$ & $\begin{array}{c}\mathrm{N}^{\circ} \text { of } \mathrm{CO}_{2} \\
\text { molecules } \\
\text { released }\end{array}$ & $\begin{array}{c}\mathrm{LHV} \\
(\mathrm{MJ} / \mathrm{kg})\end{array}$ & $\begin{array}{c}\text { Electricity } \\
\text { generated } \\
(\mathrm{MJ} / \mathrm{kg} \text { plastic) }\end{array}$ & $\begin{array}{c}\text { Emission factor } \\
\text { incineration } \\
\text { (t CO } \mathrm{CO}_{2} / \mathrm{t} \text { plastic) }\end{array}$ & $\begin{array}{c}\text { Non-emitted } \mathrm{CO}_{2} \\
\text { from the grid due to } \\
\mathrm{P} 2 \mathrm{E} \text { (t CO } \mathrm{CO}_{2} / \mathrm{t} \text { plastic) }\end{array}$ \\
\hline $\mathrm{HDPE}$ & $\mathrm{C}_{2} \mathrm{H}_{4}(28)$ & 2 & 42.47 & 9.77 & 3.14 & 1.59 \\
\hline PVC & $\mathrm{C}_{2} \mathrm{H}_{3} \mathrm{Cl}(62)$ & 2 & 21.51 & 4.95 & 1.42 & 0.81 \\
\hline PET & $\mathrm{C}_{10} \mathrm{H}_{8} \mathrm{O}_{4}(192)$ & 10 & 22.95 & 5.28 & 2.29 & 0.86 \\
\hline EPS & $\mathrm{C}_{8} \mathrm{H}_{8}(104)$ & 8 & 38.67 & 8.89 & 3.38 & 1.45 \\
\hline
\end{tabular}

$\mathrm{CO}_{2}$ emissions (0.58 $\left.\mathrm{tCO}_{2} / \mathrm{MWh}\right) .{ }^{95}$ Table 4 shows the lower heating value (LHV), the amount of electricity generated and emissions avoided from the grid for the P2E option. It is worth noting that incinerating plastics with energy recovery would mitigate emissions in the system 'P2E - grid', even though this final disposal option increases grid emissions marginally.

For the mechanical recycling option, the waste plastic needs to be shredded, extruded, and agglomerated. Electricity consumption at each step of mechanical recycling is shown in Table 4. A material loss of $10 \%{ }^{96}$ was assumed in each recycling cycle, meaning that $1 \mathrm{~kg}$ of recycled plastic avoids producing $0.9 \mathrm{~kg}$ of virgin plastic and its related emissions. Plastics undergo some degradation in each recycling cycle and the impurities may become concentrated after subsequent cycles ${ }^{35,97}$ limiting the number of cycles that they can afford. ${ }^{97}$ Recycling therefore does not guarantee that the plastic will return to the cycle with the same quality. ${ }^{45,46}$ For a closed-loop consideration, this study assumed only one recycling cycle for each plastic, following the method adopted by Shonfield. ${ }^{98}$

After one closed-loop recycling cycle, the plastic must be diverted towards another final disposal option. Hence, this study considered the association of recycling with incineration and with waste plastic post-application in longlifetime materials, called Construction and Infrastructure (C\&IF). Plastic use in C\&IF assumes that the carbon will be locked in for the period the infrastructure exists. Moreover, the plastic could substitute traditional construction materials (cement, aluminium, steel, and wood), reducing $\mathrm{CO}_{2}$ emissions in the C\&IF sector. Regarding the use of wood in the construction sector, this study assumed the use of eucalyptus, which already accounts for $72 \%{ }^{99}$ of all planted forests in Brazil, and also wood associated with deforestation in the Amazon. The emission factors of eucalyptus wood and of wood associated with deforestation were calculated based on the wood volume of the forest $\left(290 \mathrm{~m}^{3} \mathrm{ha}^{-1100,101}\right.$ 
and $180 \mathrm{~m}^{3} \mathrm{ha}^{-1,102}$ respectively), the basic density of the wood $\left(0.49 \mathrm{~g} \mathrm{~cm}^{-3103}\right.$ and $0.65 \mathrm{~g} / \mathrm{cm}^{3,104}$ respectively), and the emission factor from the silviculture of eucalyptus and from deforestation-induced land-use change (-61 $\mathrm{tCO}_{2} \mathrm{eq} /$ ha ${ }^{105,106}$ and $94.2 \mathrm{tCO}_{2} \mathrm{eq} / \mathrm{ha},{ }^{107}$ respectively). It worth noting that the use of wood from planted forest in the construction sector can also act as carbon sink, as discussed in Churkina et al.. ${ }^{30}$ However, in Brazil, the exploitation of illegal wood is still common, the Amazon forest being the main area affected by this activity. ${ }^{108,109}$ For instance, in 2017, 60\% of the wood exploration in the State of Pará was illegal. ${ }^{110}$

Every time a material is replaced by a bio-based plastic, this would reduce the emission of $\mathrm{CO}_{2}$ associated with the production of that material (see Table 5).

\begin{tabular}{|c|c|}
\hline Recycling step & Electricity consumption (kWh/t plastic) \\
\hline Shredding & 24 \\
\hline Extruders & 270 \\
\hline Agglomorators & 175 \\
\hline Total & 469 \\
\hline
\end{tabular}

Table 5. Emission factor of cement, aluminium, steel, and wood.

\begin{tabular}{lc} 
Construction material & $\begin{array}{c}\text { Emission factor } \\
\text { (t CO } 2 \text { eq/ t material) }\end{array}$ \\
Cement & 0.58 \\
\hline Aluminium & 4.44 \\
\hline${ }^{111}$ Steel & 1.84 \\
\hline Wood & -0.43 \\
\hline Wood (deforestation) & 0.80 \\
\hline MCTIC $^{112}$ and Costa & \\
\hline
\end{tabular}

It was assumed that plastics could substitute cement, aluminium, steel, and wood in a mass or volume 1:1 proportion, as in Table 6. If a 1:1 (v/v) proportion was assumed, the new emission factors would be calculated based on the materials' bulk density rates (see Table 7). It is worth noting that the material substitution rate and the selection of plastics for long-term material assumed here is a simplified method used to calculate the impacts of this measure on GHG emissions. The values adopted are fairly conservative, given that we considered only a small share of the construction materials that are widely used and that plastics would not be an alternative for structural, load-bearing materials. A more detailed evaluation of the use of plastics in infrastructure should be conducted to refine the results of this mitigation measure.

In sum, this article evaluated the following plastics' final disposal options:

- incineration (INC);

- plastic to Energy (P2E);

- recycling + incineration $(\mathrm{R}+\mathrm{INC})$;

- recycling + construction and infrastructure (R+C\&IF);

- construction and IF (C\&IF);

- construction and IF + cement substitution (C\&IF + CS);

- construction and IF + aluminium substitution (C\&IF + AS);

- construction and IF + steel substitution (C\&IF + SS);

- construction and IF + wood substitution (C\&IF + WS);

- construction and IF + wood (deforestation) substitution (C\&IF + WDS).

\section{Carbon footprint of plastics}

Figures 6-9 present the life-cycle system boundaries assessed for HDPE, PVC, PET, and EPS production, respectively. For HDPE production (Fig. 6), emissions from ethylene polymerization were estimated by deducting by ethylene

Table 6. Material substitution examples and assumptions.

\begin{tabular}{|c|c|c|c|c|}
\hline & HDPE & PVC & PET & EPS \\
\hline Cement & $\begin{array}{l}1: 1(\mathrm{~m} / \mathrm{m}) \\
\text { Plastic cement }^{79}\end{array}$ & $\begin{array}{l}1: 1(v / v) \\
\text { Water and sewage pipes }{ }^{113}\end{array}$ & $\begin{array}{l}1: 1(\mathrm{~m} / \mathrm{m}) \\
\text { Concrete }^{* 114,115}\end{array}$ & $\begin{array}{l}1: 1(\mathrm{v} / \mathrm{v}) \\
\text { EPS concrete, floor and } \\
\text { wall panels }\end{array}$ \\
\hline Aluminium & $\begin{array}{l}1: 1(\mathrm{v} / \mathrm{v}) \\
\text { Showers, cabinets }\end{array}$ & $\begin{array}{l}\text { 1:1 (v/v) } \\
\text { Pipes, Windows }{ }^{70}\end{array}$ & $\begin{array}{l}1: 1(v / v) \\
\text { Cabinets }\end{array}$ & $\mathrm{N} / \mathrm{A}$ \\
\hline Steel & $\begin{array}{l}1: 1(\mathrm{v} / \mathrm{v}) \\
\text { Non-structural applications }{ }^{\star *}\end{array}$ & $\begin{array}{l}1: 1(\mathrm{v} / \mathrm{v}) \\
\text { Non-structural applications }{ }^{\star \star}\end{array}$ & $\begin{array}{l}1: 1(\mathrm{v} / \mathrm{v}) \\
\text { Non-structural applications }{ }^{\star \star}\end{array}$ & N/A \\
\hline Wood & $\begin{array}{l}1: 1(\mathrm{v} / \mathrm{v}) \\
\text { Flooring, windows, cabinets }\end{array}$ & $\begin{array}{l}1: 1(v / v) \\
\text { Flooring, windows, Cabinets }{ }^{117}\end{array}$ & $\begin{array}{l}1: 1(\mathrm{v} / \mathrm{v}) \\
\text { Flooring, windows, cabinets }\end{array}$ & $\begin{array}{l}1: 1(v / v) \\
\text { Door linings and frames }\end{array}$ \\
\hline $\begin{array}{l}\text { Wood } \\
\text { (deforestation) }\end{array}$ & $\begin{array}{l}1: 1(\mathrm{v} / \mathrm{v}) \\
\text { Flooring, windows, cabinets }\end{array}$ & $\begin{array}{l}1: 1(\mathrm{v} / \mathrm{v}) \\
\text { Flooring, windows, Cabinets }{ }^{117}\end{array}$ & $\begin{array}{l}1: 1(\mathrm{v} / \mathrm{v}) \\
\text { Flooring, windows, cabinets }\end{array}$ & $\begin{array}{l}\text { 1:1 }(\mathrm{v} / \mathrm{v}) \\
\text { Door linings and frames }\end{array}$ \\
\hline
\end{tabular}


monomer cradle to gate GHG emissions, calculated based on Oliveira et al. ${ }^{18}$ from HDPE cradle to gate GHG emissions $\left(1.20 \mathrm{tCO}_{2} / \mathrm{t} \mathrm{HDPE}\right)^{119}$ Electricity consumption for the transformation process was based on the injection-molding process (1.47 kWh/kg HDPE). ${ }^{119}$ The estimated carbon footprint of HDPE is shown in Table 8.

For PVC production (Fig. 7), GHG emissions from chlorine production were calculated based on the electricity demand of a chlor-alkali electrolyzer ( $3000 \mathrm{kWh} / \mathrm{t}$ product), attributing $48 \%$ of mass allocation to chlorine. Electricity consumption for EDC and VCM production was based on Boulamanti and $\mathrm{Moya}^{94}$ (0.08 MWh/t EDC and 0.53 MWh/t VCM, respectively). Energy for EDC and VCM production was assumed to be produced by a fuel oil boiler with an efficiency of $85 \%$, consuming $5.30 \mathrm{MJ} / \mathrm{t} \mathrm{EDC}^{94}$ and $5.03 \mathrm{MJ} / \mathrm{t} \mathrm{VCM}^{94}$ thermal energy. The emission factor of fuel oil is based on IPCC (2006). ${ }^{120}$ Polymerization in suspension was assumed

\begin{tabular}{lc}
$\begin{array}{l}\text { Table 7. Construction and infrastructure } \\
\text { materials densities. }\end{array}$ \\
$\begin{array}{l}\text { Material } \\
\text { Plastics }\end{array}$ \\
\hline HDPE & $941-970^{116}$ \\
\hline PVC & $1380-1500^{116}$ \\
\hline PET & $1380^{116}$ \\
\hline EPS & $10-50^{116}$ \\
\hline Construction materials & \\
\hline Cement & $1440^{118}$ \\
\hline Aluminium & $2700^{116}$ \\
\hline Steel & $7850^{116}$ \\
\hline Wood & $490^{103}$ \\
\hline Wood (deforestation) & $650^{104}$ \\
\hline
\end{tabular}

with a steam consumption of $2.5 \mathrm{GJ} / \mathrm{t}$ PVC, ${ }^{130}$ being generated by a fuel oil boiler with an efficiency of $85 \%$, while electricity consumption was based on Comanita et al..$^{130}$ (0.9 GJ/t PVC). Pipe extrusion was considered for the transformation step, consuming 1.08 MWh/t PVC of electricity. The estimated carbon footprint of PVC is shown in Table 9.

Electricity consumption for ethylene oxide and monoethylene glycol (MEG) (Fig. 8) was based on Boulamanti and Moya ${ }^{94}(0.33 \mathrm{MWh} / \mathrm{t}$ ethylene oxide and $0.08 \mathrm{MWh} / \mathrm{t}$ MEG, respectively). Fuel-oil consumption for ethylene oxide and MEG production was assumed to be $3.1 \mathrm{MJ} / \mathrm{kg}$ ethylene oxide ${ }^{94}$ and $9.1 \mathrm{MJ} / \mathrm{kg}$ PET. ${ }^{94}$ For PTA production, $0.25 \mathrm{MWh} / \mathrm{t}$ PTA of electricity consumption was assumed together with steam consumption of $3.87 \mathrm{MJ} / \mathrm{kg}$ PTA, which is produced by a fuel oil boiler with an efficiency of $85 \%$. The emission factor of fuel oil is based on IPCC (2006). ${ }^{120}$ Cradle-to-gate GHG emissions for $p$-xylene was based on PlasticsEurope ${ }^{121}(1.43 \mathrm{t}$ $\mathrm{CO}_{2} \mathrm{eq} / \mathrm{t}$ p-xylene) and for acetic acid it was estimated based on CPME (2016) $)^{122}$ (0.08 $\mathrm{t} \mathrm{CO}_{2}$ eq/t PTA). Steam consumption for PET polymerization was assumed to be $2.71 \mathrm{GJ} / \mathrm{t} \mathrm{PET},{ }^{123}$ being generated by a fuel oil boiler with an efficiency of $85 \%$, while electricity consumption was assumed to be $0.19 \mathrm{MWh} / \mathrm{t}$ PET. ${ }^{123}$ Gate-to-gate GHG emissions of the subsequent polymerization step (solid-state polymerization) was also included in the PET polymerization step $\left(0.10 \mathrm{t} \mathrm{CO}_{2} \mathrm{eq} / \mathrm{t}\right.$ PET). ${ }^{124}$ Blow molding was considered for the transformation step, consuming $1.47 \mathrm{MWh} / \mathrm{t}$ PET of electricity. The estimated carbon footprint of PET is shown in Table 10.

Cradle-to-gate GHG emissions for benzene (Fig. 9) was based on PlasticsEurope ${ }^{121}\left(1.86 \mathrm{t} \mathrm{CO}_{2}\right.$ eq/t benzene) and for pentane was based on PlasticsEurope ${ }^{125}\left(1.4 \mathrm{t} \mathrm{CO}_{2} \mathrm{eq} / \mathrm{t}\right.$ benzene). Electricity consumption for ethylbenzene and styrene was based on Boulamanti and Moya ${ }^{94}(0.03 \mathrm{MWh} / \mathrm{t}$ ethylbenzene and $0.12 \mathrm{MWh} / \mathrm{t}$ styrene, respectively). Steam

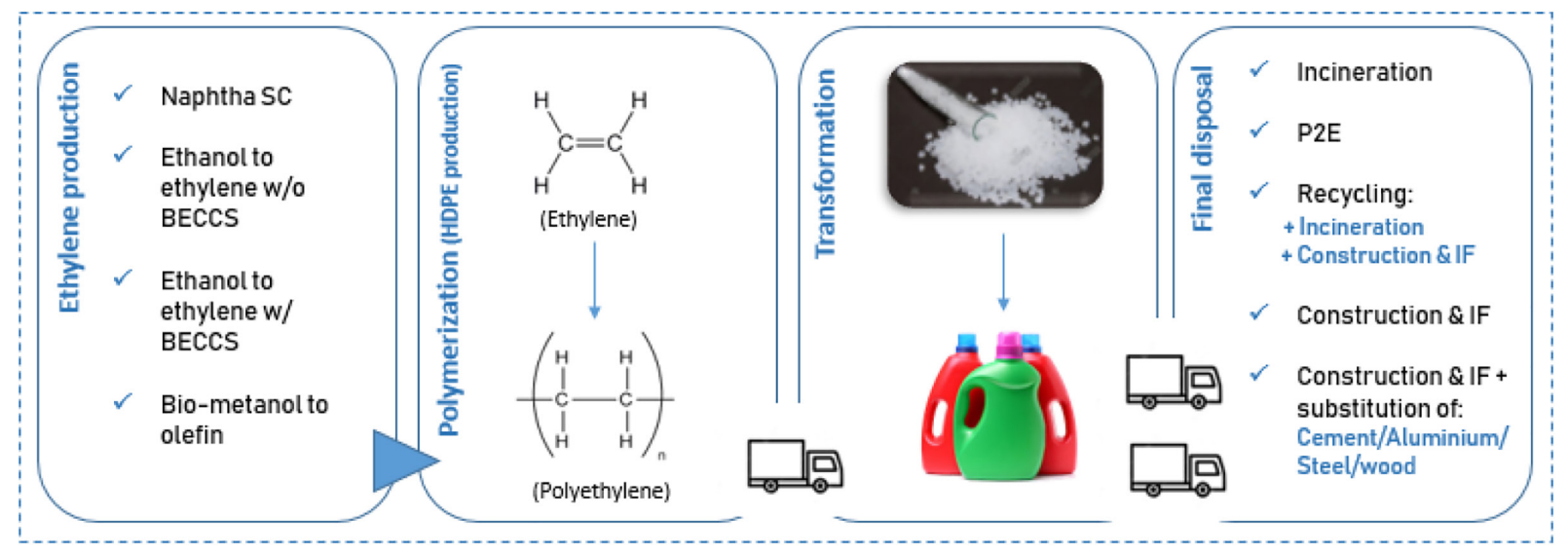

Figure 6. Life-cycle system boundaries for HDPE production. 


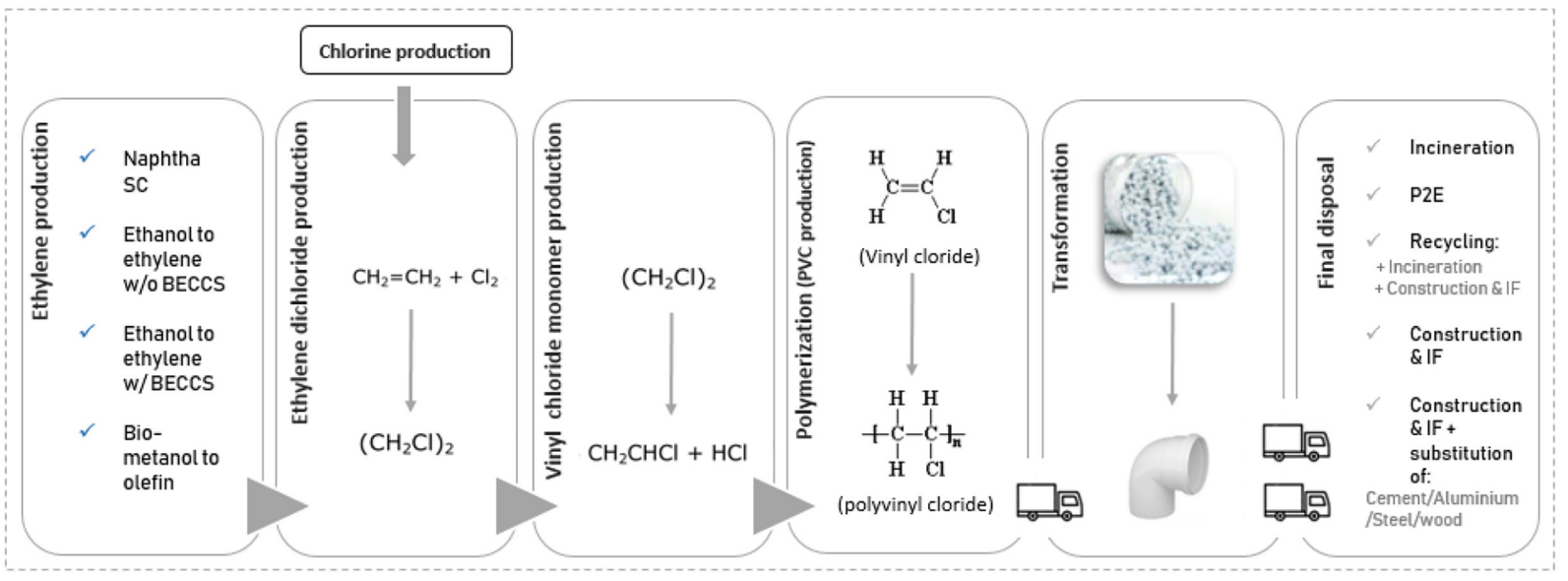

Figure 7. Life-cycle system boundaries for PVC production.

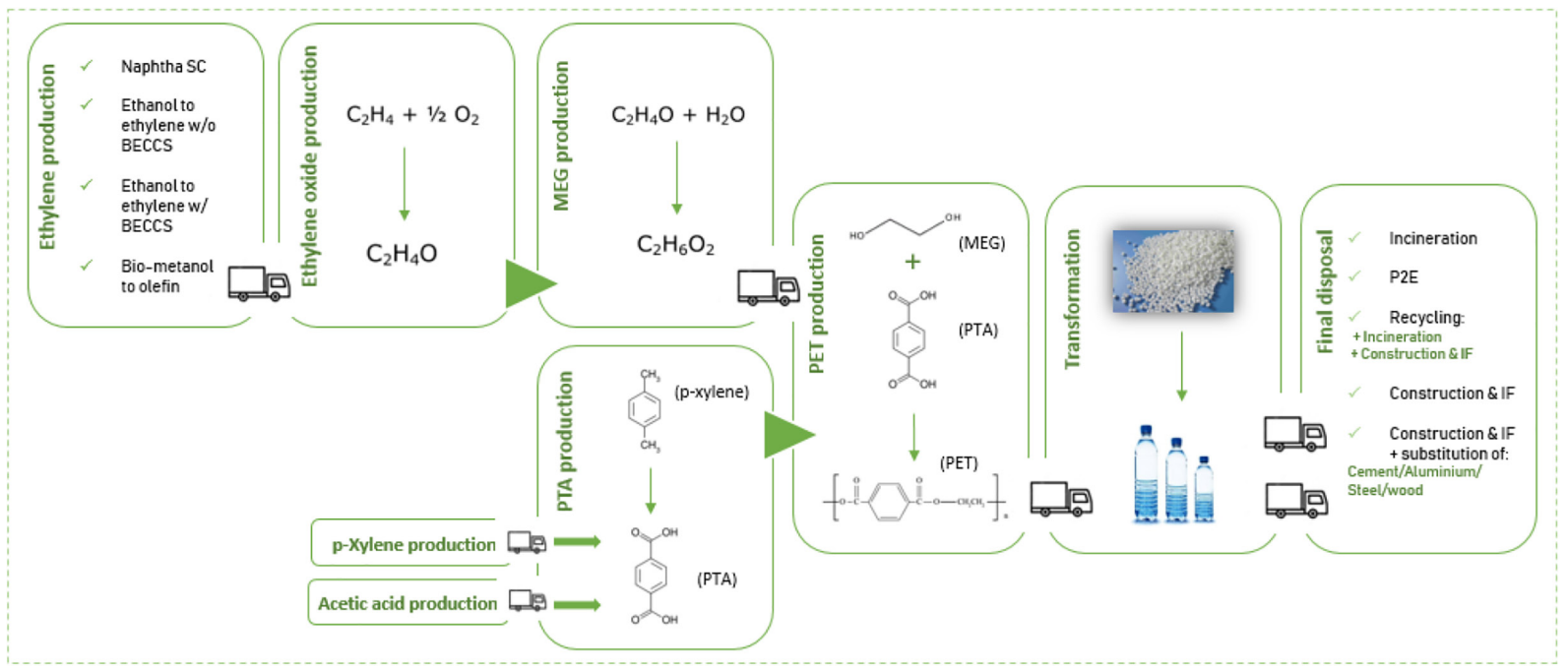

Figure 8. Life-cycle system boundaries for PET production.

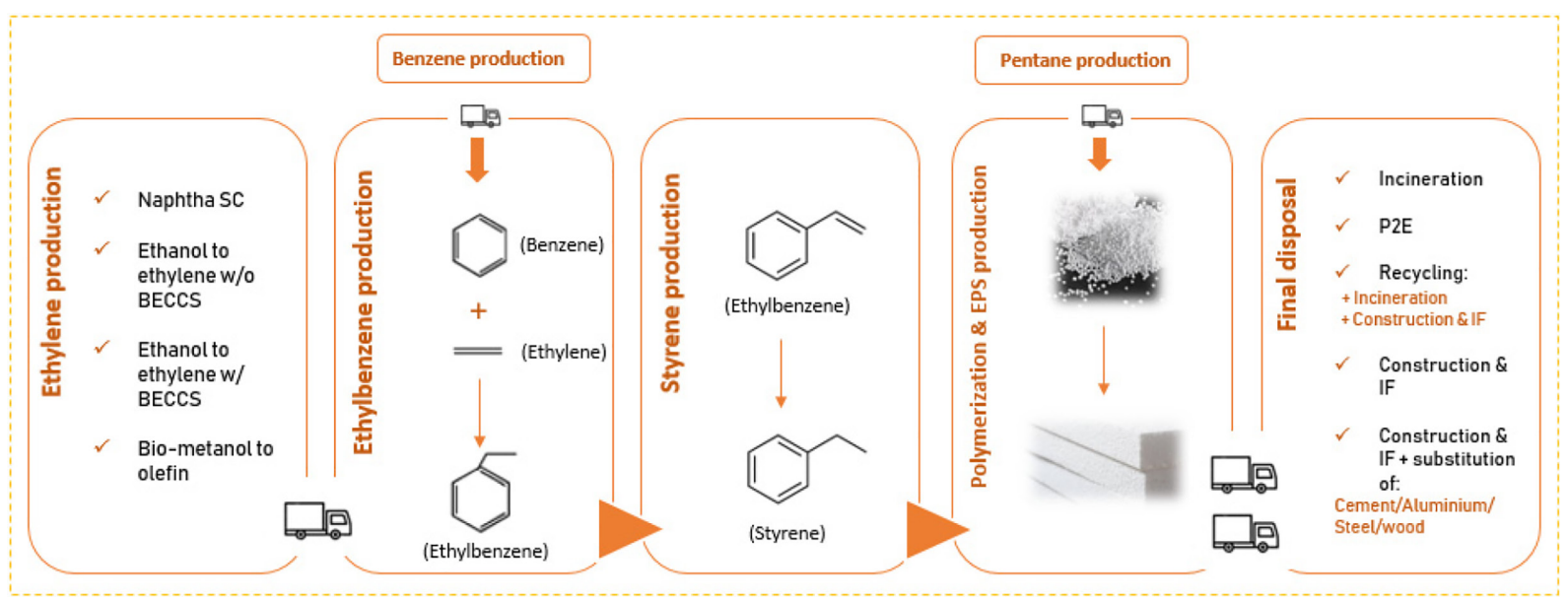

Figure 9. Life-cycle system boundaries for EPS production. 


\section{Table 8. Carbon footprint of HDPE.}

\begin{tabular}{lc}
\hline Steps & $\begin{array}{c}\text { Emission factor } \\
\text { (tCO }\end{array}$ eq/ t HDPE) \\
Ethylene production & 1.07 \\
\hline Naphtha steam-cracking & 0.18 \\
\hline Ethanol to ethylene w/o BECCS & -0.42 \\
\hline Ethanol to ethylene w/ BECCS & 0.43 \\
\hline Bio-methanol to olefins & 0.13 \\
\hline Polymerization & 0.01 \\
\hline Transportation to transformation & 0.86 \\
\hline Transformation & 0.01 \\
\hline Transportation to distributors & 0.01 \\
\hline Transportation to final disposal & \\
\hline Final disposal & 0.28 \\
\hline Recycling & 3.14 \\
\hline Incineration & 1.55 \\
\hline P2E & 0.00 \\
\hline Construction \& IF & \\
\hline Oliveira et al.., ${ }^{89}$ Platts, ${ }^{93}$ Boulamanti, ${ }^{94}$ MCTIC, ${ }^{95}$ Shonfield, ${ }^{98}$ \\
Nimana et al..
\end{tabular}

\section{Table 9. Carbon footprint of PVC.}

\begin{tabular}{lc} 
Steps & $\begin{array}{c}\text { Emission factor } \\
\left(\mathrm{tCO}_{2} \mathrm{eq} / \mathrm{t} \mathrm{PVC}\right)\end{array}$ \\
\hline Ethylene production & 0.48 \\
\hline Naphtha steam-cracking & 0.08 \\
\hline Ethanol to ethylene w/o BECCS & -0.19 \\
\hline Ethanol to ethylene w/ BECCS & 0.19 \\
\hline Bio-methanol to olefins & 0.51 \\
\hline Chlorine production & 0.89 \\
\hline EDC production & 0.56 \\
\hline VCM production & 0.37 \\
\hline Polymerization & 0.01 \\
\hline Transportation to transformation & 0.64 \\
\hline Transformation & 0.01 \\
\hline Transportation to distributors & 0.01 \\
\hline Transportation to final disposal & \\
\hline Final disposal & 0.28 \\
\hline Recycling & 1.42 \\
\hline Incineration & 0.61 \\
\hline P2E & 0.00 \\
\hline Construction \& IF & \\
\hline Oliveira et al. ${ }^{18}$ Platts, ${ }^{93}$ Boulamanti, ${ }^{94}{ }^{\text {MCTIC }}{ }^{95}$ Shonfield, ${ }^{98}$ \\
\hline Nimana et al.. & \\
\hline
\end{tabular}

consumption for ethylbenzene and styrene production was assumed as $2.98 \mathrm{GJ} / \mathrm{t}$ ethylbenzene ${ }^{94}$ and $6.57 \mathrm{GJ} / \mathrm{t}$ styrene, ${ }^{94}$ respectively, being generated by a fuel oil boiler

\section{Table 10. Carbon footprint of PET.}

Steps

Emission factor ( $\mathrm{tCO}_{2}$ eq/ t PET)

Ethylene production

\begin{tabular}{|c|c|}
\hline Naphtha steam-cracking & 0.21 \\
\hline Ethanol to ethylene w/o BECCS & 0.03 \\
\hline Ethanol to ethylene w/ BECCS & -0.09 \\
\hline Bio-methanol to olefins & 0.09 \\
\hline Ethylene transportation & 0.01 \\
\hline Ethylene oxide production & 0.05 \\
\hline Ethylene oxide transportation & 0.01 \\
\hline MEG production & 0.02 \\
\hline MEG transportation & 0.01 \\
\hline $\mathrm{p}$-xylene production & 0.81 \\
\hline $\mathrm{p}$-xylene transportation & 0.01 \\
\hline Acetic acid production & 0.07 \\
\hline Acetic acid transportation & 0.01 \\
\hline PTA production & 0.13 \\
\hline Polymerization & 0.21 \\
\hline Transporte to transformation & 0.01 \\
\hline Transformation & 0.86 \\
\hline Transportation to distributors & 0.01 \\
\hline Transportation to final disposal & 0.01 \\
\hline \multicolumn{2}{|l|}{ Final disposal } \\
\hline Recycling & 0.28 \\
\hline Incineration & 2.29 \\
\hline P2E & 1.43 \\
\hline Construction \& IF & 0.00 \\
\hline
\end{tabular}

with an efficiency of $85 \%$. For EPS production, an electricity consumption of $0.16 \mathrm{MWh} / \mathrm{t}$ EPS $^{126}$ and steam consumption of $1.29 \mathrm{GJ} / \mathrm{t}$ EPS was assumed. ${ }^{126}$ It was also assumed that the steam would be generated by a fuel oil boiler with an efficiency of $85 \%$. The estimated carbon footprint for EPS is shown in Table 11.

\section{Results and discussions}

Figures 10-17 present the carbon footprint of each plastic for the options that achieve the highest (ethylene from steam cracking of naphtha) and the lowest (ethanol to ethylene with BECCS) life-cycle GHG emissions. The results that include ethanol to ethylene without BECCS and bio-methanol to olefins routes can be found in the supplementary material. Table 12 presents the options that achieve the highest and lowest carbon footprints (with and without credits) and 
the corresponding final disposal options for all the plastics assessed. In our study, the difference between 'total emission with credits' and 'total emission without credits' stands for the $\mathrm{CO}_{2}$ credits given (or not) for material substitution; for avoiding ethylene production and transportation when the waste plastic is recycled; and for avoiding electricity generation in P2E. These credits are not considered in 'total emissions without credits', which aims to reveal the cases in which bioplastics achieve negative emissions, i.e. when lifecycle emissions do not surpass photosynthetic $\mathrm{CO}_{2}$ capture, thus effectively removing $\mathrm{CO}_{2}$ from the atmosphere. Carbon dioxide capture was also disaggregated in the results so that the emissions, credits, and capture in each of the various steps could be compared.

The results presented in Figs 10-17 and in the supplementary material show that the routes that could be considered NETs are those in which the total emissions w/o credits' is below zero. Negative $\mathrm{CO}_{2}$ emissions are only achieved in bio-based HDPE, PET, and EPS production and the best case is always when ethylene is produced from sugarcane ethanol with BECCs and the final disposal option is the C\&IF sector.

\section{Table 11. Carbon footprint of EPS.}

\begin{tabular}{|c|c|}
\hline Steps & $\begin{array}{l}\text { Emission factor } \\
\left(\mathrm{tCO}_{2} \text { eq/ } \mathrm{t} \text { EPS }\right)\end{array}$ \\
\hline \multicolumn{2}{|l|}{ Ethylene production } \\
\hline Naphtha steam-cracking & 0.28 \\
\hline Ethanol to ethylene w/o BECCS & 0.04 \\
\hline Ethanol to ethylene w/ BECCS & -0.12 \\
\hline Bio-methanol to olefins & 0.11 \\
\hline Ethylene transportation & 0.01 \\
\hline Benzene production & 1.48 \\
\hline Benzene transportation & 0.01 \\
\hline Ethylbenzene production & 0.30 \\
\hline Styrene production & 0.64 \\
\hline Pentane production & 0.10 \\
\hline Pentane transportation & 0.01 \\
\hline EPS production & 0.09 \\
\hline Transportation to distributors & 0.01 \\
\hline Transportation to final disposal & 0.01 \\
\hline \multicolumn{2}{|l|}{ Final disposal } \\
\hline Recycling & 0.28 \\
\hline Incineration & 3.38 \\
\hline P2E & 1.94 \\
\hline Construction \& IF & 0.00 \\
\hline $\begin{array}{l}\text { Oliveira et al.., }{ }^{18} \text { Platts, }{ }^{93} \text { Boulaman } \\
\text { Nimana et al.. }{ }^{89}\end{array}$ & C, ${ }^{95}$ Shonfield, ${ }^{98}$ \\
\hline
\end{tabular}

The exception, therefore, is bio-based PVC. For biobased plastics production, 3.14t $\mathrm{CO}_{2} / \mathrm{t} \mathrm{HDPE}, 1.42 \mathrm{tCO}_{2} / \mathrm{t}$ $\mathrm{PVC}, 2.29 \mathrm{tCO}_{2} / \mathrm{t} \mathrm{PET}$ and $3.38 \mathrm{tCO}_{2} / \mathrm{t} \mathrm{EPS}$ are captured in sugarcane cultivation. In bio-PVC production, because bio-based ethylene makes up for just a small portion of PVC's molecular weight, life-cycle emissions surpass the $\mathrm{CO}_{2}$ photosynthetic capture. The production of bio-based PVC in Brazil may therefore never result in negative emissions, unless EDC, VCM, and chlorine production emissions can be substantially reduced.

In some cases, where mitigation efforts surpass life-cycle emissions, net negative values are achieved. Though they do not represent negative emissions, it is implied that the overall emissions are reduced due to avoided feedstock production, electricity consumption, or traditional energy-intensive construction materials production. This is the case for all fossil-based plastics applied in the C\&IF sector substituting: (i) aluminium or steel for HDPE, PVC and PET; and (ii) cement or deforestation wood for EPS.

When considering emissions with credits, the worst case (highest emission option) is the 'recycling + incineration' option for all plastics and feedstocks assessed, except for fossilbased PET (worst case: 'incineration') and fossil and bio-based EPS (worst case: 'construction and IF + wood substitution'). For fossil-based plastics, 'recycling + incineration' is usually the highest due to the 1-cycle recycling assumption, which makes recycling emissions surpass credits from avoided ethylene production. In other words, emissions from incineration are only postponed and the virgin material production emissions that are avoided are not that relevant. When considering that plastics undergo more recycling cycles, recycling final disposal options tend to become less emission-intensive.

The 'recycling + incineration' option for bio-based plastics achieves a higher carbon footprint when credits are considered because of the demand reduction of virgin bio-based ethylene (from ethanol or bio-methanol). Thus, it reduces the potential of carbon capture from sugarcane cultivation and BECCS. In addition, the more recycling cycles bioplastics undergo, the more carbon capture is avoided, which means that, for bio-based plastics, recycling is not the best final disposal when negative carbon emissions are the goal.

For fossil and bio-based EPS, 'construction and IF + wood substitution' is the worst case when considering credits because of the lower bulk density of EPS compared to other plastics. As wood from planted forests captures $-0.43 \mathrm{tCO}_{2} / \mathrm{t}$ wood, less carbon is captured if it is substituted in volume by EPS. On the other hand, when considering credits, the highest capture and mitigation option achieved is when EPS is produced from bio-ethylene with CCS and applied in 'construction and IF' substituting cement, also because of its lightweight property. 


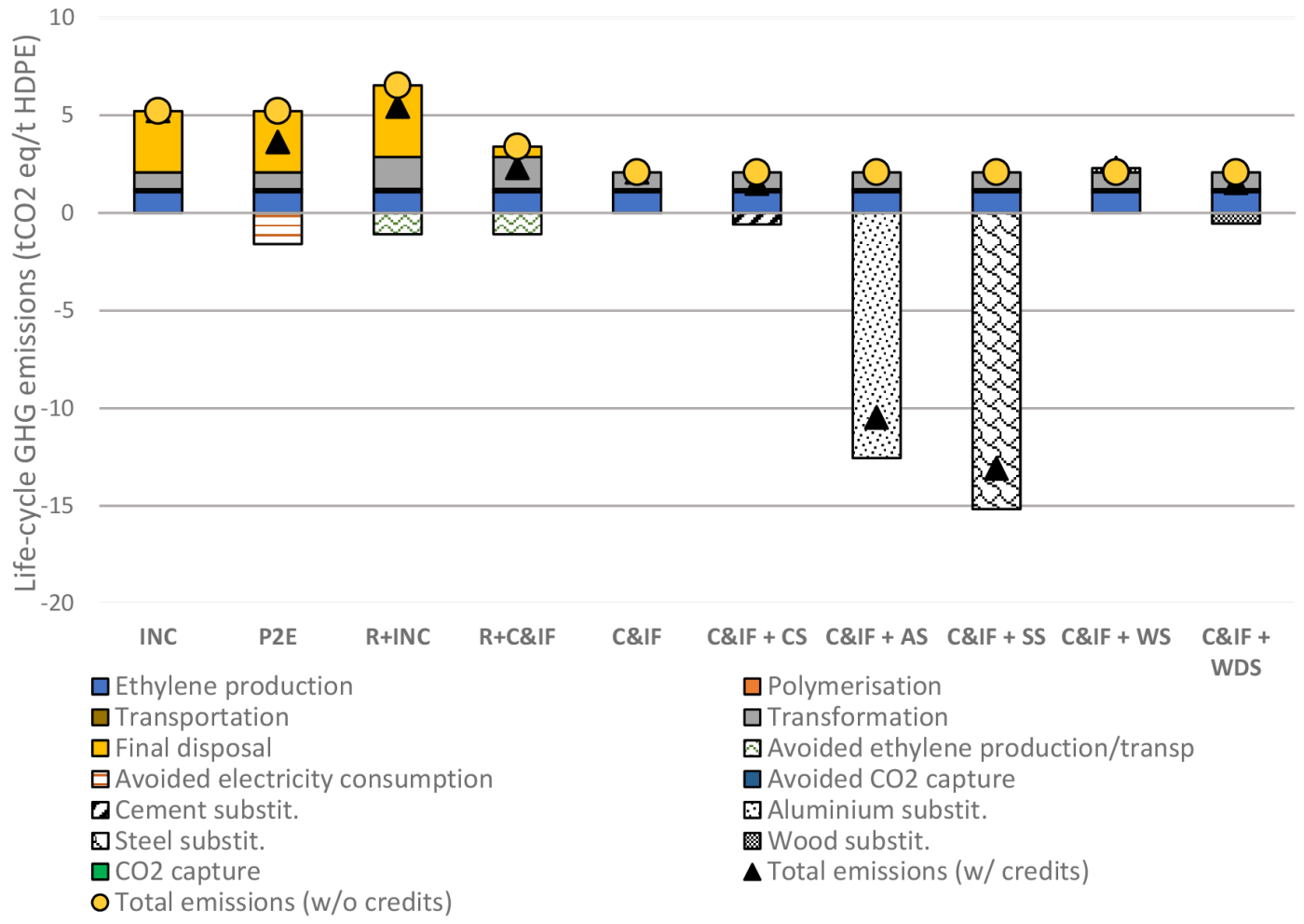

Figure 10. Carbon footprint for HDPE (ethylene from steam cracking of naphtha).

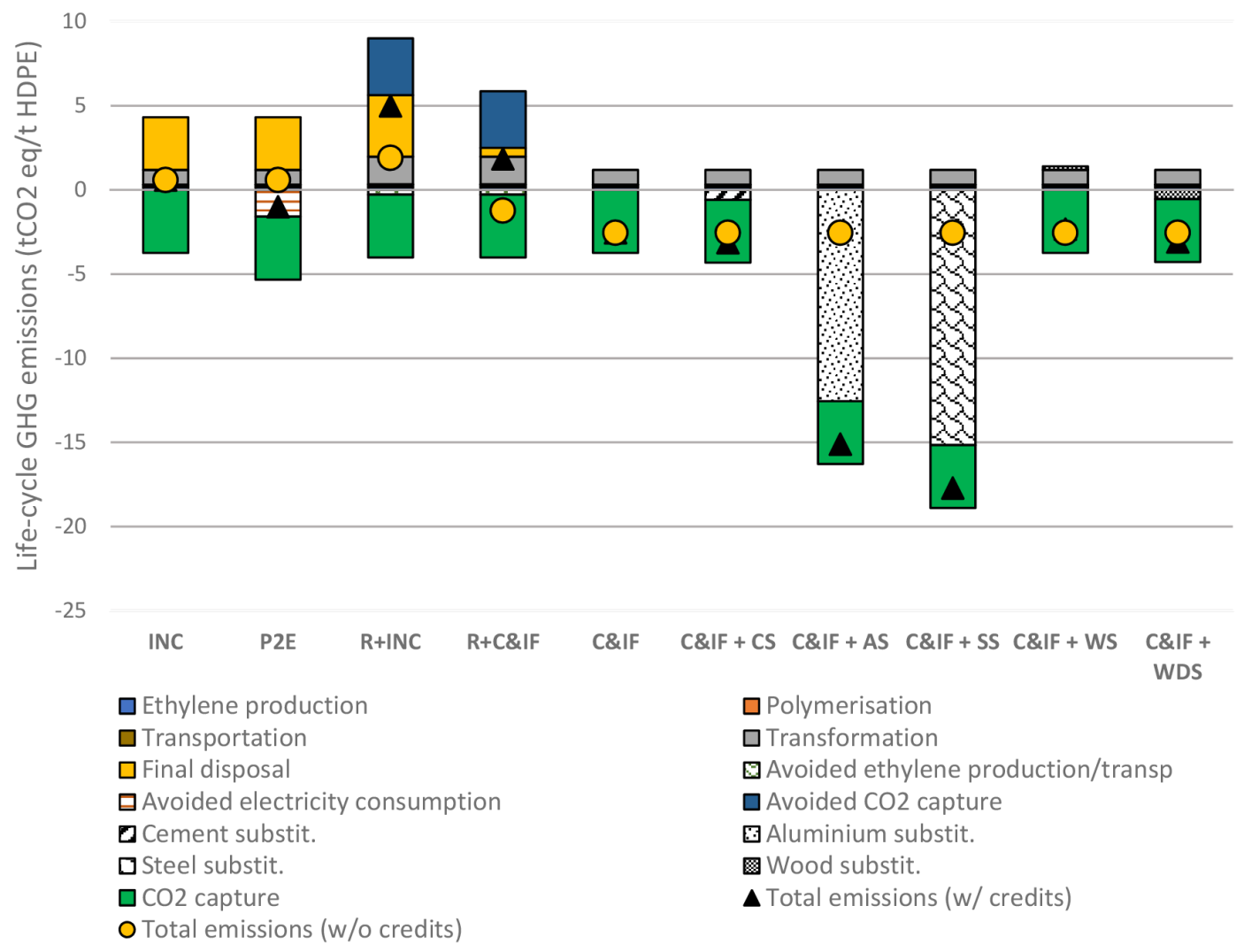

Figure 11. Carbon footprint for HDPE (ethanol to ethylene with BECCS). 


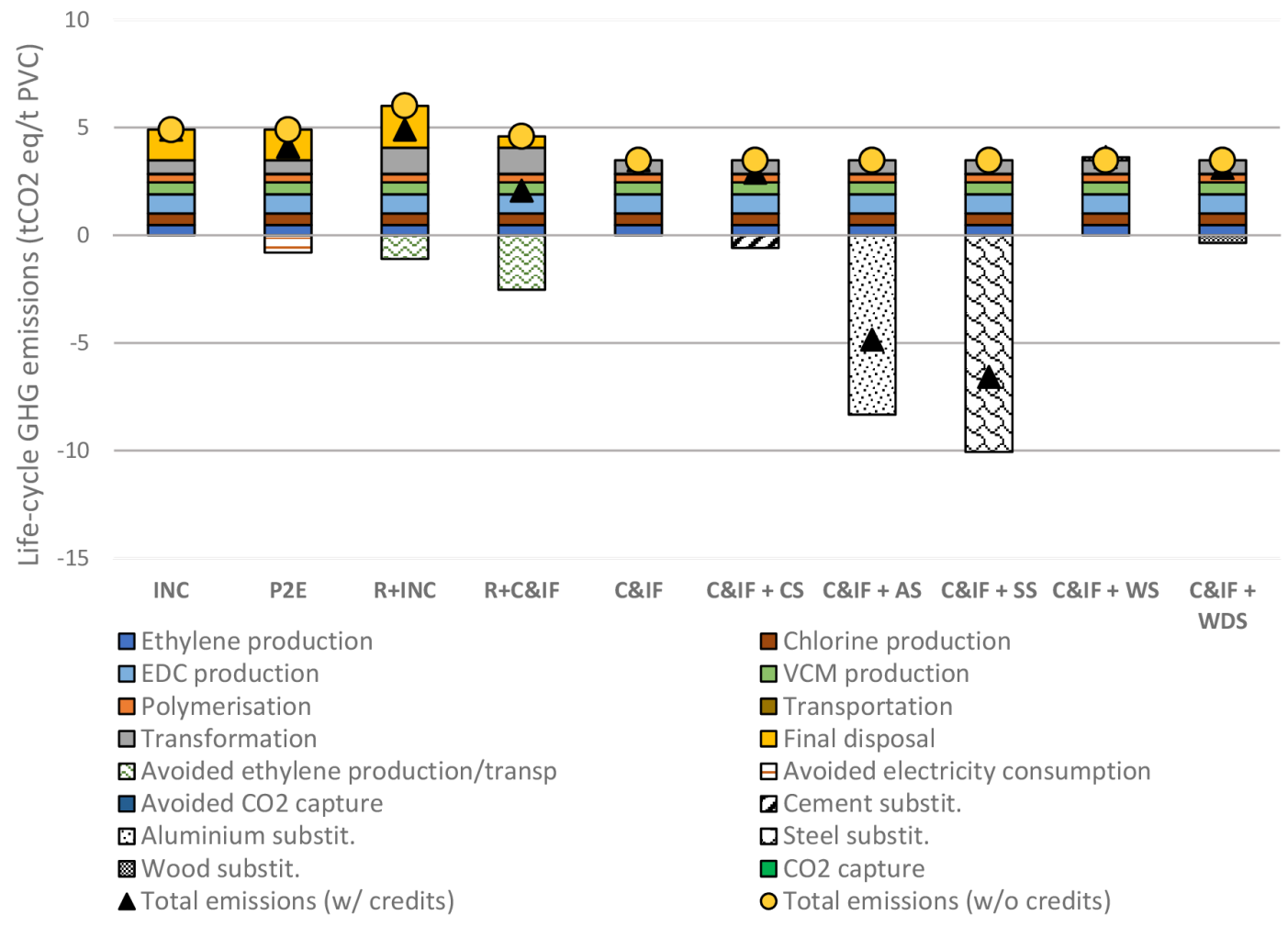

Figure 12. Carbon footprint for PVC (ethylene from steam cracking of naphtha).

10

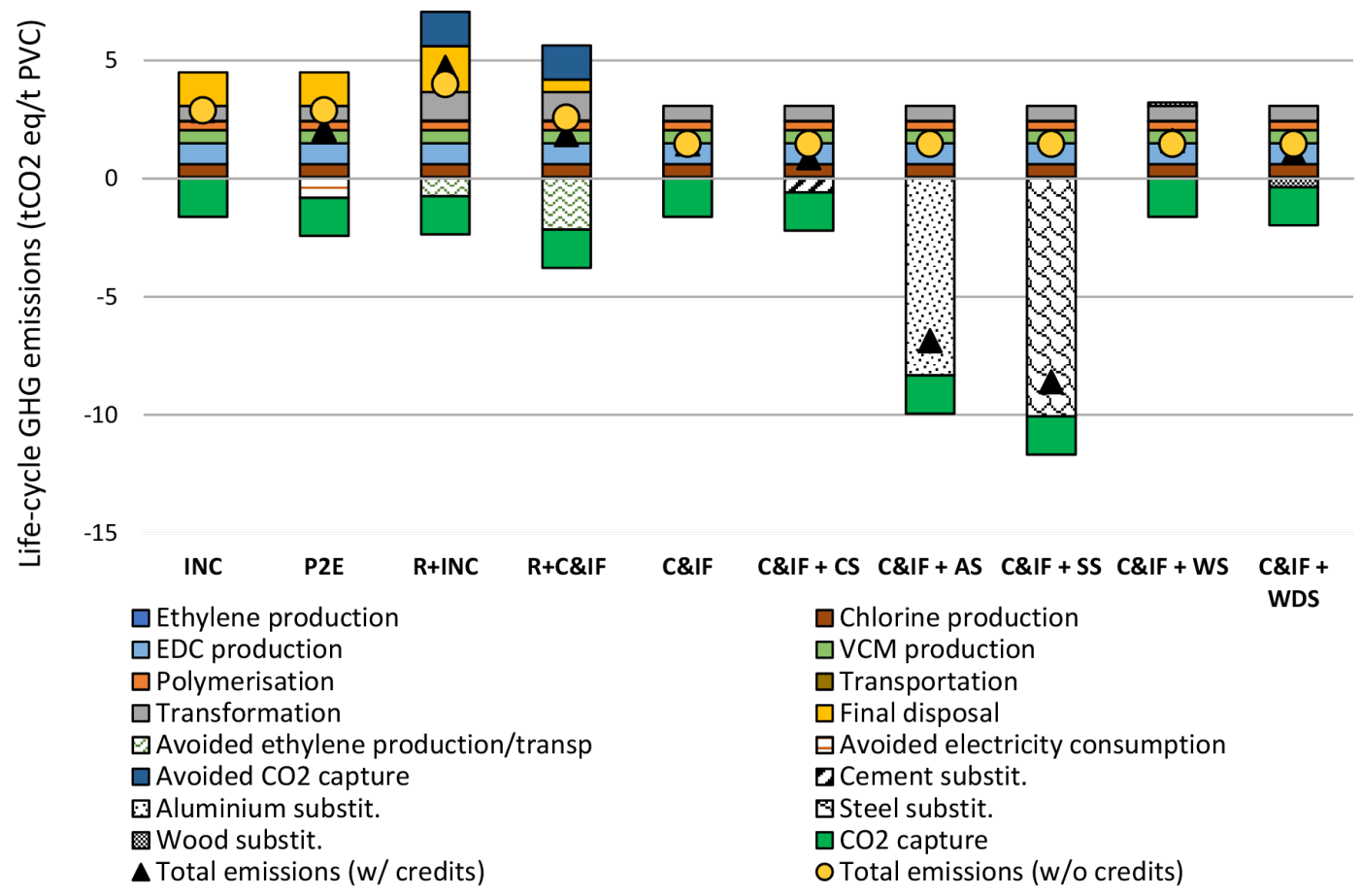

Figure 13. Carbon footprint for PVC (ethanol to ethylene with BECCS). 


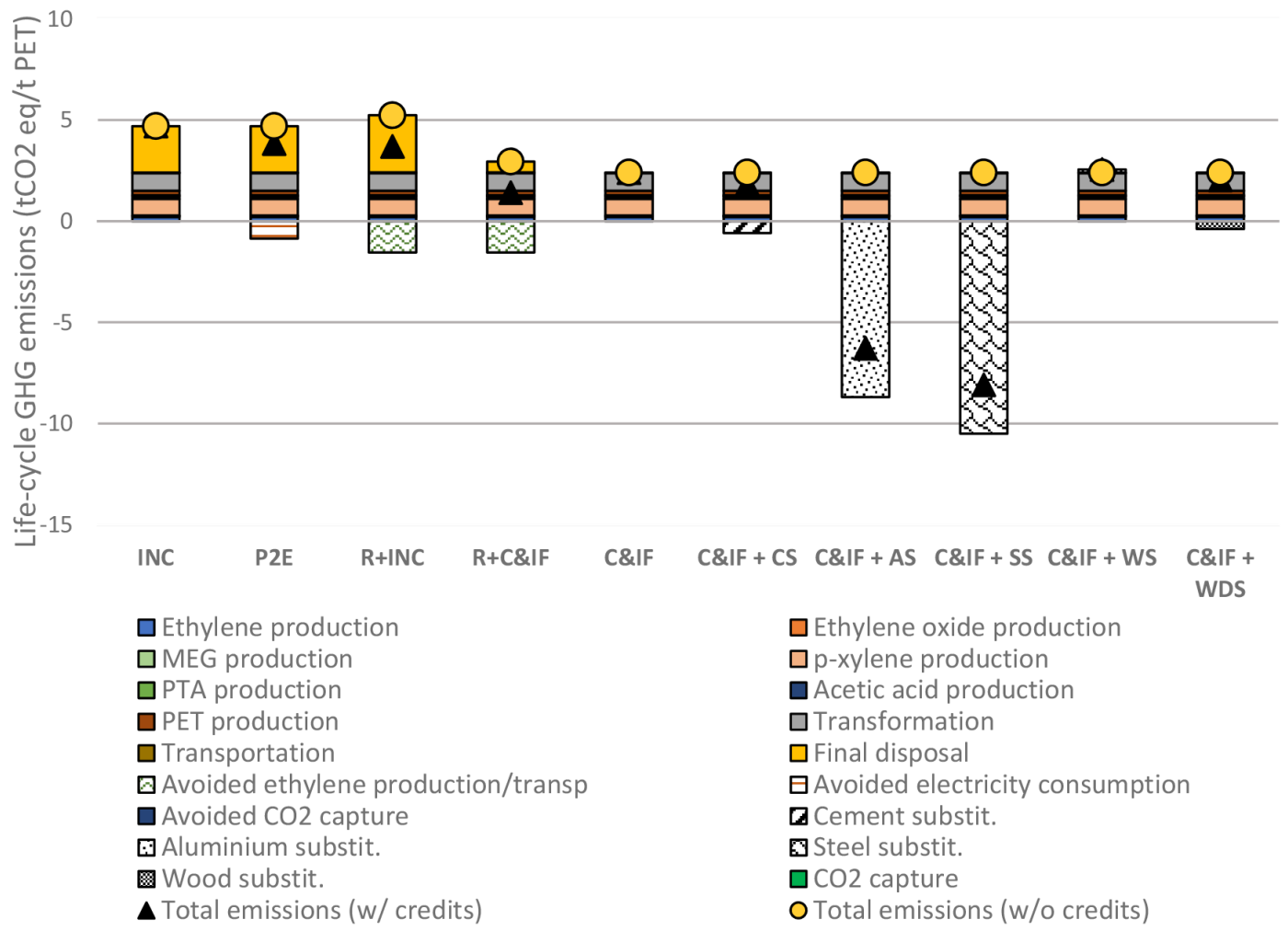

Figure 14. Carbon footprint for PET (ethylene from steam cracking of naphtha).

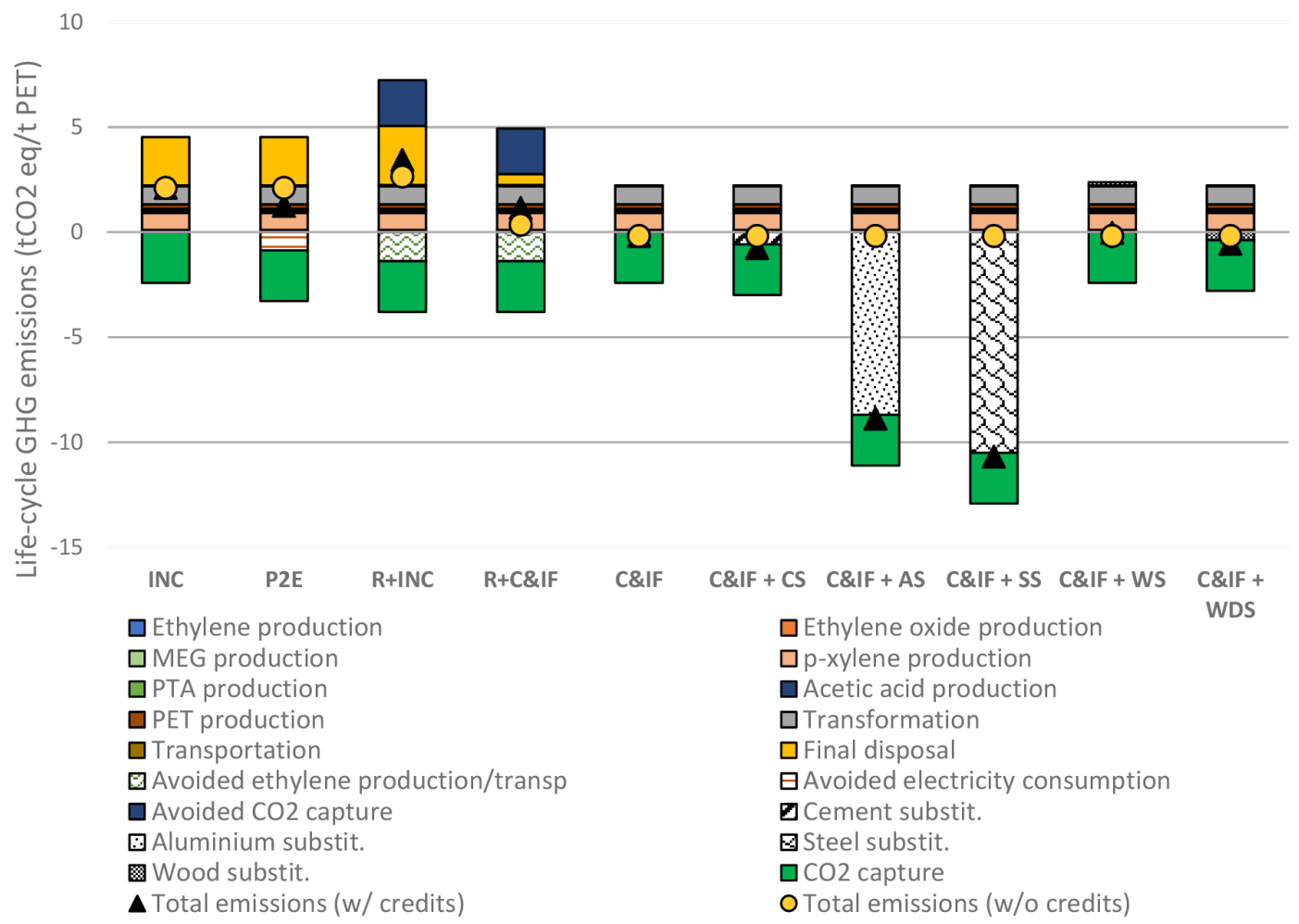

Figure 15. Carbon footprint for PET (ethanol to ethylene with BECCS). 


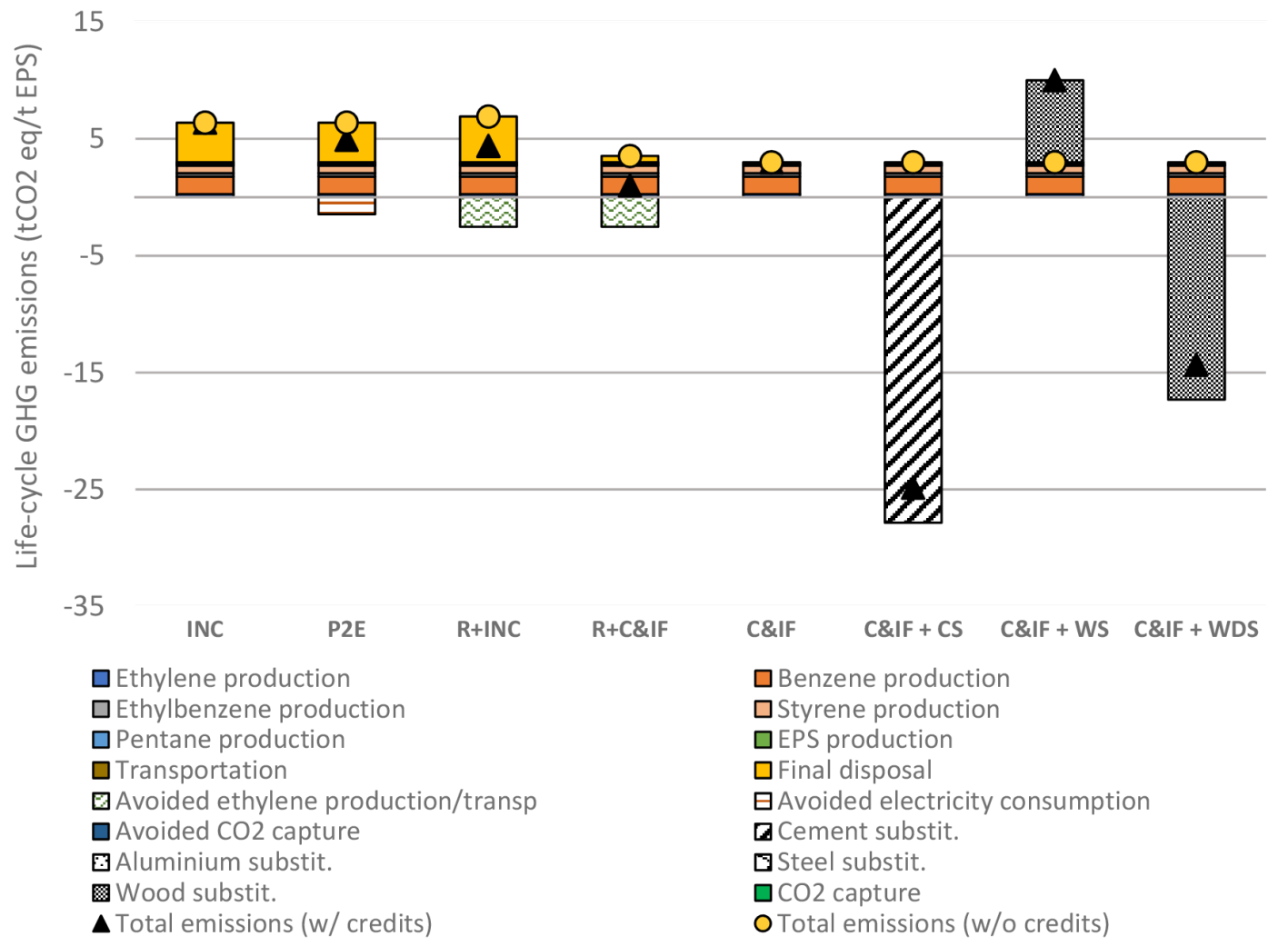

Figure 16. Carbon footprint for EPS (ethylene from steam cracking of naphtha).

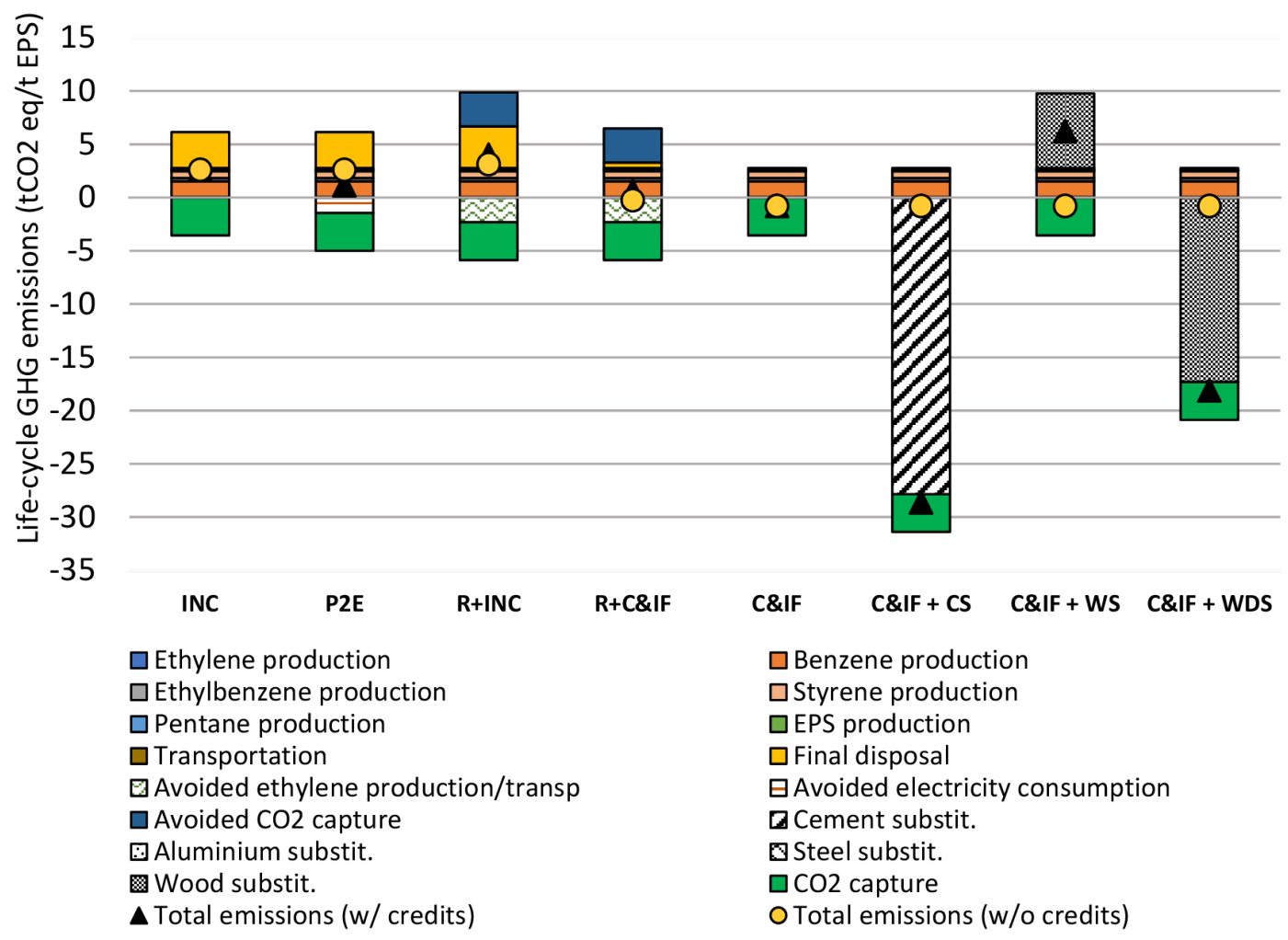

Figure 17. Carbon footprint for EPS (ethanol to ethylene with BECCS). 
Table 12. Carbon footprints of HDPE, PVC, PET and EPS.

\begin{tabular}{|c|c|c|c|c|c|c|c|c|}
\hline \multirow[b]{3}{*}{ HDPE } & \multicolumn{4}{|c|}{ Highest GHG emission option } & \multicolumn{4}{|c|}{ Lowest GHG emission option } \\
\hline & $\begin{array}{l}\text { With } \\
\text { credits }\end{array}$ & FD & $\begin{array}{l}\text { Without } \\
\text { credits }\end{array}$ & FD & $\begin{array}{l}\text { With } \\
\text { credits }\end{array}$ & FD & $\begin{array}{l}\text { Without } \\
\text { credits }\end{array}$ & FD \\
\hline & \multicolumn{8}{|c|}{$\mathrm{tCO}_{2} / \mathrm{t} \mathrm{HDPE}$} \\
\hline Steam-cracking of naphtha & 5.45 & $\mathrm{R}+\mathrm{INC}$ & 6.54 & $\mathrm{R}+\mathrm{INC}$ & -13.08 & C\&IF + SS & 2.08 & C\&IF \\
\hline Ethanol to ethylene w/o BECCS & 5.05 & $\mathrm{R}+\mathrm{INC}$ & 2.50 & $\mathrm{R}+\mathrm{INC}$ & -17.11 & C\&IF + SS & -1.95 & C\&IF \\
\hline Ethanol to ethylene w/ BECCS & 4.99 & $\mathrm{R}+\mathrm{INC}$ & 1.91 & $\mathrm{R}+\mathrm{INC}$ & -17.71 & C\&IF + SS & -2.55 & C\&IF \\
\hline Bio-methanol & 5.07 & $\mathrm{R}+\mathrm{INC}$ & 2.76 & $\mathrm{R}+\mathrm{INC}$ & -16.86 & C\&IF + SS & -1.70 & C\&IF \\
\hline PVC & \multicolumn{8}{|c|}{$\mathrm{tCO}_{2} / \mathrm{tPVC}$} \\
\hline Steam-cracking of naphtha & 4.91 & $\mathrm{R}+\mathrm{INC}$ & 6.01 & $\mathrm{R}+\mathrm{INC}$ & -6.57 & C\&IF + SS & 3.48 & C\&IF \\
\hline Ethanol to ethylene w/o BECCS & 4.73 & $\mathrm{R}+\mathrm{INC}$ & 4.19 & $\mathrm{R}+\mathrm{INC}$ & -8.40 & C\&IF + SS & 1.66 & C\&IF \\
\hline Ethanol to ethylene w/BECCS & 4.71 & $\mathrm{R}+\mathrm{INC}$ & 4.00 & $\mathrm{R}+\mathrm{INC}$ & -8.59 & C\&IF + SS & 1.47 & C\&IF \\
\hline Bio-methanol & 4.74 & $\mathrm{R}+\mathrm{INC}$ & 4.31 & $\mathrm{R}+\mathrm{INC}$ & -8.28 & C\&IF + SS & 1.78 & C\&IF \\
\hline PET & \multicolumn{8}{|c|}{$\mathrm{tCO}_{2} / \mathrm{t} \mathrm{PET}$} \\
\hline Steam-cracking of naphtha & 4.70 & INC & 5.24 & $\mathrm{R}+\mathrm{INC}$ & -8.09 & C\&IF + SS & 2.41 & C\&IF \\
\hline Ethanol to ethylene w/o BECCS & 3.45 & $\mathrm{R}+\mathrm{INC}$ & 2.77 & $\mathrm{R}+\mathrm{INC}$ & -10.56 & C\&IF + SS & -0.06 & C\&IF \\
\hline Ethanol to ethylene w/ BECCS & 3.44 & $\mathrm{R}+\mathrm{INC}$ & 2.65 & $\mathrm{R}+\mathrm{INC}$ & -10.68 & C\&IF + SS & -0.18 & C\&IF \\
\hline Bio-methanol & 3.45 & $\mathrm{R}+\mathrm{INC}$ & 2.82 & $\mathrm{R}+\mathrm{INC}$ & -10.51 & C\&IF + SS & -0.01 & C\&IF \\
\hline EPS & \multicolumn{8}{|c|}{$\mathrm{tCO}_{2} / \mathrm{t} \mathrm{EPS}$} \\
\hline Steam-cracking of naphtha & 10.02 & C\&IF + WS & 6.92 & $\mathrm{R}+\mathrm{INC}$ & -24.84 & C\&IF + CS & 3.00 & C\&IF \\
\hline Ethanol to ethylene w/o BECCS & 6.39 & C\&IF + WS & 3.30 & $\mathrm{R}+\mathrm{INC}$ & -28.46 & C\&IF + CS & -0.62 & C\&IF \\
\hline Ethanol to ethylene w/BECCS & 6.23 & C\&IF + WS & 3.14 & $\mathrm{R}+\mathrm{INC}$ & -28.62 & C\&IF + CS & -0.78 & C\&IF \\
\hline Bio-methanol & 6.46 & C\&IF + WS & 3.37 & $\mathrm{R}+\mathrm{INC}$ & -28.39 & C\&IF + CS & -0.55 & C\&IF \\
\hline
\end{tabular}

Finally, when the BECCS in the ethanol production is considered for bio-based plastics, the carbon footprint of bio-ethylene is lower $\left(-0.41 \mathrm{t} \mathrm{CO}_{2} \mathrm{eq} / \mathrm{t}\right.$ ethylene) than the one without BECCS ( $0.16 \mathrm{t} \mathrm{CO}_{2} \mathrm{eq} / \mathrm{t}$ ethylene), as reported in Table 2. This negative emission potential in the bioethylene production step accumulates into the bio-based plastic production sequential steps. Then, options that include 'construction and IF' preserve the net negative emission potential of bio-based plastics, as they store biogenic carbon. The best case for each ethylene derivative plastic is therefore based on bio-ethylene produced with BECCS.

For illustration, considering a baseline scenario for HDPE demand (1.5\% a.a. starting in 2010$)$ and also considering that by 2050 this demand will be covered $100 \%$ by bio-based HDPE, $32.35 \mathrm{MtCO}_{2}$ of accumulated NETs will be achieved if the use of HDPE in construction increases $2.0 \%$ p.a. in the same period. In this example, NETs represent less than $1 \%$ of the BECCS required to meet targets consistent with Brazil's contribution to a $2{ }^{\circ} \mathrm{C}$ world. ${ }^{108}$
The results indicate that the advantages of bio-based plastic and even fossil-based plastic are enhanced by their use in longlifetime materials. As of today, the main destination of plastics is not for construction purposes. However, under the desired carbon transition focus, the associated material transition could be based on the production of biodegradable plastics with short lifetimes from biomass, and the production of the basic plastics oriented towards constructive uses. There would be room for this needed material transition in the desired low carbon transition, which will depend on growing materials demands to build the new renewable-based energy conversion facilities, the infrastructure for big data and energy transmission networks (fibers), and the smart buildings, cities and mobility. This means a transition in materials along with the low carbon transition.

\section{Conclusions}

Our findings show that using plastics as long life-time materials could lead to net negative GHG emissions (NETs), depending on the feedstock, the polymer and the 
strategy for its final disposal. Fossil-based plastics could also mitigate GHG emissions when credits are given for material substitution in the construction sector. The final disposal of the polymer is therefore more relevant than its feedstock when emissions reduction in the plastic life cycle is desired. Particularly in times of climate emergency, an opportunity arises, when producing plastics for long-term applications, to reduce the carbon footprint. Low carbon transition policies should therefore be developed to promote the use of plastic in the construction sector, placing the chemical sector as potential enabler of NETs, and the use of biodegradable plastics for short-lifetime applications.

Results also show that bio-based HDPE, bio-based PET and bio-based EPS can be considered NETs when used in the construction sector. For PVC, negative values in emissions balance were achieved only when accounting the substitution of aluminium and steel for fossil-based PVC or any other material for bio-based PVC. This indicates that bio-based PVC may mitigate but not achieve negative emissions.

For fossil-based plastics, negative emissions balance values are achieved only when they are used in construction, substituting the aluminium and steel content, indicating an interesting mitigation strategy for the fossil-based plastics industry. Actually, these final disposal options represent the lowest carbon footprint of three out of the four plastics (HDPE, PVC, PET) and for all ethylene production routes assessed (steam cracking of naphtha, ethanol to ethylene without BECCS, ethanol to ethylene with BECCS, biomethanol to olefins). This result was expected as the emission factors of aluminium and steel production are higher than those associated with the other materials assessed. On the other hand, as it is unlikely that EPS substitute aluminium or steel extensively, we excluded it from our analysis. Hence, the lowest carbon footprint options for EPS are when it is substituted for cement and deforestation wood.

Even though our study has a global scope and could be reproduced for other countries, the assumption of replacing wood by plastics in construction is very specific for Brazil as illegal wood exploitation there is far above world average.

Recycling once (without plastic downcycling) and then sending the plastic waste to incineration was the worst option in terms of carbon footprint, not considering credits, for all types of (bio-based and fossil) plastics assessed. Recycling, in this case, delays rather than avoids emissions from final disposal.

Considering recycling as final disposal, life-cycle GHG emissions of bio-based plastics are higher when credits are included than when they are not. Each recycling cycle avoids the production of virgin bio-based ethylene, which, in turn, avoids the capture of biogenic carbon from biomass cultivation. In terms of GHG emissions, therefore, recycling makes sense only for fossil-fuel based plastics. Our study assumed that the recycling of fossil-based plastics replaces virgin fossil-based plastics and the recycling of bio-based plastics replaces virgin bio-based plastics, which is a limitation of our study because the recycling of the bio-based plastics replaces mostly fossil-based virgin materials. Still, applying it in the construction and IF sector is a better option, apart from EPS when substituting planted forest wood. Furthermore, the analysis did not consider indirect environmental benefits provided by a greater participation of plastics in the construction \& IF sector, such as better insulation, which could reward extra carbon credits for reduction of fuel consumption.

Although bio-based ethylene and bio-based HDPE is already produced by Braskem in Brazil, ${ }^{127}$ the cost of biobased plastics production will hardly ever be competitive with that of their fossil-based counterparts. Proper incentives - financial and policy design - to support bio-based plastics development will be critical considering their demonstrated potential to play the role of NETs for limiting global warming to $1.5^{\circ} \mathrm{C}$. When designing such incentives, the level of reward of each technology should also account for the level of benefit produced, i.e. policy-making should provide additional incentives to carbon removal (NET) compared to carbon reduction (mitigation technologies).

Hence, if the plastic industry adapts to the imperatives of the 21 st century - climate emergency and plastic pollution - by changing its feedstock and purpose, it could become a NET, little-waste-generating industry. This, in turn, would represent a technology that would provide both private (housing, insulation, lower cost) and collective, social (climate alleviation and waste reduction) benefits. Although the material substitution assumptions made by this study may not be exactly precise, the results indicate that a shift to construction and IF is an attractive opportunity for the plastics industry.

However, a weakness of this study stems from the assumption that the use of plastic in the construction sector is final disposal, neglecting the next final disposal this plastic would have at the end of the construction lifetime. It is worth noting that the use of plastics in the C\&IF sector - with current standards - could delay their final disposal for around 35 years ${ }^{15}$ (or more), enabling carbon storage until later than 2050 , and therefore addressing the critical issue of reducing emissions in the short-term. It would also be easier to dispose the plastics permanently concentrated in one use (C\&IF), in scale and location, than in a dispersed manner as occurs with single-use plastics. Given the urgency to achieve net zero $\mathrm{CO}_{2}$ emissions around 2050, to limit global warming 
to $1.5^{\circ} \mathrm{C}, 127$ the strategy of changing the feedstock - from fossil to renewable - and the main application of plastics from single-use to long term-use - tested in this study would contribute to this global effort. Moreover, delaying emissions would itself have a role in delaying the handling of waste plastics to a future when advanced recycling techniques would be commercially available.

While this approach already leads to relevant climate benefits, this is only the worst-case scenario since waste plastic would need proper handling after an around 35 years lifetime. A much more ambitious concept is proposed here. Since the physico-chemical properties of plastics enable their use in very long applications - virtually thousands of years - our core argument is that the strategy for the plastics industry should rely on designing bio-based non-degradable plastics for C\&IF purposes for longer periods of time and providing proper disposal. Yet, it is important to stress that these plastics can only be considered NETs if an appropriate regulatory framework is established to ensure that the carbon photosynthetically captured will be stored in windows, floorings, cabinets, for several decades, before being correctly disposed or reused.

Uncertainties also rely on the assumption that, for PVC, chlorine is produced on site; for PET, $p$-xylene and acetic acid are produced off site; for EPS, benzene and pentane are produced off site. Depending on the petrochemical plant, these intermediate products are produced on site or off site, thus demanding transportation in the last case. Uncertainties also arise from the simplification made for defining the substitution rate between plastics and common emissionintensive materials. This should be better evaluated in further studies given the relevance of the replacement of steel and aluminium in our findings. Actually, detailed research on the substitution of traditional material construction by plastic should be conducted to understand the real potential of plastic in the construction sector.

It is worth noting that, if only plastic's carbon footprint is investigated, sending plastic waste to landfill, open dumps or littering it in the natural environment could be also an option to achieve NETs. However, those final disposal options are not encouraged by policy because they create local pollution and harm natural ecosystems, even though they could bring climatic benefit due to NETs.

This study did not investigate the direct and indirect impacts of biomass use on the energy-food-materials competition, and did not test, for instance, if NETs achieved by plastics would impact the remaining carbon emission budgets of other economic sectors. Moreover, the demand reduction of naphtha for material purposes could impact emissions from the refining sector, because the emergence of biorefineries to provide bio-based energy and feedstock could lead to the reduction of petroleum refining utilization rates, impacting the production of oil derivatives for energy purposes. To fill this gap, we incorporated a biomass trilemma (instead of the usual food-energy dilemma) in the Brazilian Land Use and Energy System (BLUES) model, which represents biomass competition between energy, food and materials, given land, GHG emissions (from fuel combustion and direct and indirect land use change) and water availability constraints. The results of this study are presented in Oliveira et al. ${ }^{128}$

Further studies should also evaluate life-cycle GHG emissions for other plastics, such as those derived from propylene and aromatics, as well as other routes of ethylene production. The methodology applied here could also be adjusted to other countries with different grid emission factors, chemical industries, and biomass feedstock.

Finally, future research should include the evaluation of plastic chemical recycling. Although this recycling method is not readily available, it could have a great impact on the results of this study because it contributes to material circularity, closing the plastic loop. In this case, if the monomer is repurposed to something other than a fuel, the plastic carbon would be stored for as many cycles as possible without downgrade, performing similarly to being stored in buildings and infrastructure. However, given that this process is not spontaneous (being energy consuming and GHG emitting), it is safe to say that the carbon footprint would necessarily be higher (or less negative, in the case of biogenic carbon) than storing plastic carbon in long-lifetime products.

\section{Acknowledgements}

We would like to thank the National Council for Scientific and Technological Development (Conselho Nacional de Desenvolvimento Científico e Tecnológico - CNPq) for financial support. This work also received funding from the NAVIGATE project of the European Union's Horizon 2020 research and innovation program under grant agreement 821124 .

\section{References}

1. IEA. The future of petrochemicals. (2018). https://doi. org/10.1787/9789264307414-en

2. Geyer R, Jambeck JR and Law KL, Production, use, and fate of all plastics ever made. Sci Adv 3:19-24 (2017).

3. World Steel Association. World Steel Association (WSA), "Steel Statistical Yearbooks 1978 to 2016". (2017).

4. (USGS), U. S. G. S. Information, Cement Statistics and Information (2017).

5. Gu $L$ and Ozbakkaloglu $T$, Use of recycled plastics in concrete: a critical review. Waste Manag 51:19-42 (2016). 
6. PlasticsEurope, Plastics -The facts 2018. Plast Eur (2018). https://www.plasticseurope.org/application/ files/6315/4510/9658/Plastics_the_facts_2018_AF_web.pdf.

7. Monteiro, A. da R. D. Contribuição da Reciclagem Química de Resíduos Plásticos para o Desenvolvimento Sustentável III, (2018).

8. Pinto, J. C. Impactos Ambientais Causados pelos Plásticos. Rio de Janeiro: e-papers Serviços Editoriais Ltda. (2012).

9. Laskar $\mathrm{N}$ and Kumar U, Plastics and microplastics: a threat to environment. Environ Technol Innov 14:100352 (2019).

10. GEF. Plastics and the circular economy. 1-23 (2018).

11. Jefferson M, WHITHER PLASTICS?-petrochemicals, plastics and sustainability in a garbage-riddled world. Energy Res Soc Sci 56:101229 (2019).

12. McKinsey Center \& Ocean Conservancy. Stemming the tide. Land-based strategies for a plastic - free ocean 47 (2015).

13. MacArthur $\mathrm{E}$, The new plastics economy: rethinking the future of plastics \& catalysing action. Ellen MacArthur Found 74:68 (2017). https://doi.org/10.1103/Physrevb.74.035409.

14. UN Environment. Single-use Plastics: A Roadmap for Sustainability (2018).

15. Geyer R, Jambeck JR and Law KL, Production, use, and fate of all plastics ever made. Sci Adv 3:25-29 (2017). https://doi. org/10.1126/sciadv.1700782.

16. IEA. Tracking Progress: Chemicals and petrochemicals. (2017). Available: https://www.iea.org/etp/tracking2017/ chemicalsandpetrochemicals/ accessed date June 6th, 2020.

17. Bauer F, Karin E, Hasselbalch J, Nielsen T and Nilsson L, Climate innovations in the plastic industry: Prospects for decarbonisation 26:111 (2018).

18. Oliveira C, Rochedo P, Bhardwaj R, Worrell E and Szklo A, Bio-ethylene from sugarcane as a competitiveness strategy for the Brazilian chemical industry. Biofuels Bioprod Bioref 3:86-93 (2020).

19. Spierling $S$, Knüpffer E, Behnsen $H$, Mudersbach $M$, Krieg H, Springer S et al., Bio-based plastics - a review of environmental, social and economic impact assessments. J Clean Prod 185:476-491 (2018).

20. Zheng $J$ and Suh S, Strategies to reduce the global carbon footprint of plastics. Nat Clim Chang 9:374-378 (2019).

21. IPCC. Summary for Policymakers. Global Warming of $1.5^{\circ} \mathrm{C}$. An IPCC Special Report on the impacts of global warming of $1.5^{\circ} \mathrm{C}$ above pre-industrial levels. Global Warming of $1.5^{\circ} \mathrm{C}$. An IPCC Special Report on the impacts of global warming of $1.5^{\circ} \mathrm{C}$ above pre-industrial levels and related global greenhouse gas emission pathways, in the context of strengthening the global response to the threat of climate change, (2018). https://doi.org/10.1017/CBO9781107415324

22. Tanzer SE and Ramírez A, When are negative emissions negative emissions? Energ Environ Sci 12:1210-1218 (2019).

23. UNFCC. Adoption of the Paris Agreement. Report opf the Conference of the Parties, hel din Paris from 30 November to 11 December 2015. 21932, 1-32 (2015).

24. Smith P, Davis SJ, Creutzig F, Fuss S, Minx J, Gabrielle B et al., Biophysical and economic limits to negative $\mathrm{CO} 2$ emissions. Nat Clim Chang 6:42-50 (2016).

25. Krey V, Luderer G, Clarke L and Kriegler E, Getting from here to there - energy technology transformation pathways in the EMF27 scenarios. Clim Change 123:369-382 (2014).

26. Daioglou V, Doelman JC, Wicke B, Faaij A and van Vuuren $\mathrm{DP}$, Integrated assessment of biomass supply and demand in climate change mitigation scenarios. Glob Environ Chang 54:88-101 (2019).
27. Daioglou V, Faaij APC, Saygin D, Patel MK, Wicke B and van Vuuren DP, Energy demand and emissions of the non-energy sector. Energ Environ Sci 7:482-498 (2014).

28. Daioglou V, Wicke B, Faaij APC and van Vuuren DP, Competing uses of biomass for energy and chemicals: implications for long-term global CO 2 mitigation potential. GCB Bioenergy 7:1321-1334 (2015).

29. Lap T, Benders R, Köberle A, van der Hilst F, Nogueira L, Szklo A et al., Pathways for a Brazilian biobased economy: towards optimal utilization of biomass. Biofuels Bioprod Biorefin 13:673-689 (2019).

30. Churkina G, Organschi A, Reyer CPO, Ruff A, Vinke K, Liu Z et al., Buildings as a global carbon sink. Nat Sustain 2020:1-8 (2020). https://doi.org/10.1038/s41893-019-0462-4.

31. UNEP. Single-use Plastics: A Roadmap for Sustainability (2018).

32. Franklin Associates. Life Cycle Impacts of Plastic Packaging Compared to Substitutes in the United States and Canada. (2018).

33. Chen L, Pelton REO and Smith TM, Comparative life cycle assessment of fossil and bio-based polyethylene terephthalate (PET) bottles. J Clean Prod 137:667-676 (2016).

34. Liptow $C$ and Tillman AM, A comparative life cycle assessment study of polyethylene based on sugarcane and crude oil. J Ind Ecol 16:420-435 (2012).

35. WRAP. LCA of management options for mixed waste plastics. Waste resource action programme WRAP (2008). doi:1-81105-397-0

36. Chen Y, Cui Z, Cui X, Liu W, Wang X, Li XX et al., Life cycle assessment of end-of-life treatments of waste plastics in China. Resour Conserv Recycl 146:348-357 (2019). accessed date June 20th, 2020.

37. Sule J, Emmanuel Sule, Joseph Ismaila, Ibhadobe Osagie Ibhadobe1, Alfred Buba Y, Waziri Farida Idris et al., Use of waste plastics in cement-based composite for lightweight concrete production. Int J Res Eng Technol 2:44-54 (2017). accessed date May 14th, 2020.

38. EBC. BRAZIL: Plastic ban to come into force in São Paulo city. (2019). Available: https://agenciabrasil.ebc.com.br/en/ geral/noticia/2019-06/plastic-bags-banned-rio-markets

39. Latin News. Brazil: Plastic ban to come into force in São Paulo city. (2020). Available: https://www.latinnews.com/ component/k2/item/82807-brazil-plastic-ban-to-come-intoforce-in-sao-paulo-city.html

40. WWF. Solucionar a Poluição Plástica: Transparência e Responsabilização (2019).

41. UNEP. Mapping of global plastics value chain and plastics losses to the environment (with a particular focus on marine environment). 1-99 (2018).

42. Bhattacharya RRNS, Chandrasekhar K, Deepthi MV, Roy $P$ and Khan A, Challenges and opportunities: plastic waste management in India. Energy Resour Inst 24:3-7 (2018).

43. Worrell, E. The circular economy and the search for a new economic paradigm. Available: https://www.uu.nl/en/research/ copernicus-institute-of-sustainable-development/the-circulareconomy-and-the-search-for-a-new-economic-paradigm.

44. Worrell, E. \& Reuter, M. A. Handbook of recycling: stateof-the-art for practitioners, analysts, and scientists. (2014). https://doi.org/10.1016/C2011-0-07046-1. accessed date February 17th, 2020.

45. Dilkes-Hoffman LS, Pratt S, Laycock B, Ashworth P and Lant PA, Public attitudes towards plastics. Resour Conserv Recycl 147:227-235 (2019). 
46. Flock. The difference between recycling and circular economy - radio interview. 2018 (2018). Available: http:// www.flockcircular.com.br/en/the-difference-betweenrecycling-and-circular-economy/.

47. Eriksen MK, Christiansen JD, Daugaard AE and Astrup TF, Closing the loop for PET, PE and PP waste from households: influence of material properties and product design for plastic recycling. Waste Manag 96:75-85 (2019).

48. Hopewell J, Dvorak R and Kosior E, Plastics recycling: challenges and opportunities. Philos Trans $R$ Soc B Biol Sci 364:2115-2126 (2009). accessed date March 28th, 2020.

49. OECD. Improving Plastics Management: Trends, policy responses, and the role of international co-operation and trade. (2018). https://doi.org/10.1126/sciadv.1700782, 3, e1700782

50. World Economic Forum. Germany recycles more than any other country. 2017 (2017). Available: https://www.weforum. org/agenda/2017/12/germany-recycles-more-than-anyother-country/.

51. Sustainable Recycling Industries. Feasibility study for a certification of sustainably recycled plastics in India. (2018).

52. USEPA. Advancing sustainable materials management: 2015 Fact Sheet Assessing Trends in Material Generation, Recycling, Composting, Combustion with Energy Recovery and Landfilling in the United States. United States Environmental Protection Agency, Office of Land and Emergency Management Washington, DC 2046022 (2018). doi:EPA530F-18-004. accessed date July 7th, 2020.

53. Greenpeace. The recycling myth. 1-48 (2018). accessed date July 7th, 2020.

54. National Geographic. How China's Plastic Waste Ban Forced a Global Recycling Reckoning. 2019 Available: https://www. nationalgeographic.com/magazine/2019/06/china-plasticwaste-ban-impacting-countries-worldwide/. accessed date July 7th, 2020.

55. DW. After China's import ban, where to with the world's waste? 2019 Available: https://www.dw.com/en/after-chinasimport-ban-where-to-with-the-worlds-waste/a-48213871.

56. Ministry of Ecology and Environment. National Development and Reform Commission. Opinions on Further Strengthening the Control of Plastic Pollution. (2020). Available: https://www. ndrc.gov.cn/xxgk/zcfb/tz/202001/t20200119_1219275.html.

57. Ragaert K, Delva L and Van Geem K, Mechanical and chemical recycling of solid plastic waste. Waste Manag 69:24-58 (2017).

58. Faraca $G$ and Astrup T, Plastic waste from recycling centres: characterisation and evaluation of plastic recyclability. Waste Manag 95:388-398 (2019).

59. Eriksen MK, Pivnenko K, Olsson ME and Astrup TF, Contamination in plastic recycling: influence of metals on the quality of reprocessed plastic. Waste Manag 79:595-606 (2018). accessed date April 10th, 2020.

60. Rudolph Natalie, Kiesel Raphael and Aumnate Chuamchom, Understanding plastics recycling, in Understanding Plastics Recycling. Munich: Hanser; (2017). https://doi. org/10.3139/9781569906774.fm.

61. Parliament, E. Circular economy: definition, importance and benefits. 2018 Available: http://www.europarl.europa.eu/ news/en/headlines/economy/20151201STO05603/circulareconomy-definition-importance-and-benefits.

62. Grigore M, Methods of recycling, properties and applications of recycled thermoplastic polymers. Dent Rec 2:24 (2017).

63. Perugini F, Mastellone ML and Arena U, A life cycle assessment of mechanical and feedstock recycling options for management of plastic packaging wastes. Environ Prog 24:137-154 (2005). https://doi.org/10.1002/ep.10078.
64. Hou P, Xu Y, Taiebat M, Lastoskie C, Miller SA and Xu M, Life cycle assessment of end-of-life treatments for plastic film waste. J Clean Prod 201:1052-1060 (2018).

65. UK WIN. United Kingdom without incineration network. 2018, (2019).

66. Verma R, Vinoda KS, Papireddy M and Gowda ANS, Toxic pollutants from plastic waste- a review. Procedia Environ Sci 35:701-708 (2016). accessed date April 22, 2020.

67. GEF. Cities and the Circular Economy. 3-34 (2018).

68. Zero Waste Europe. The not-that-well hidden risks of incineration: the case of the Danish Norfors Plant. (2019). Available: https://zerowasteeurope.eu/2019/07/the-case-ofthe-danish-norfors-plant/.

69. Hamilton, L. A., Feit, S., Muffett, C. \& Kelso, M. Plastic \& Climate: The hidden costs of plastic planet. 1-108 (2019). accessed date June 18th, 2020.

70. SPI. Building and Construction Plastics-Building for a more sustainable. (2016). accessed date June 18th, 2020.

71. The Constructor. Properties of plastics as a construction material. 2019 Available: https://theconstructor.org/building/ plastics-construction-material/12438/. accessed date June 19th, 2020.

72. PlasticsEurope. Plastics in building and construction. (2017). Available: http://www.plasticseurope.org/use-of-plastics/ building-construction.aspx.

73. Institute of Building Structures and Structural Design. Research Project Bioplastic Facade. (2013). Available: https://www.itke.uni-stuttgart.de/.

74. PlasticsEurope - Association of Plastics Manufacturers, Plastic insulation - a sustainable solution. PlasticsEurope:1-6 (2011). accessed date June 19th, 2020.

75. Lackner, M. Bioplastics - Biobased plastics as renewable and/or biodegradable alternatives to petroplastics. KirkOthmer Encyclopedia of Chemical Technology, 6th ed. (2015). https://doi.org/10.1002/0471238961.koe00006

76. ABAL. Reciclagem no Brasil. (2020). Available: http://abal. org.br/sustentabilidade/reciclagem/reciclagem-no-brasil/.

77. PlasticRoad. PlasticRoad - A Revolution in Building Roads. 2019 Available: https://www.plasticroad.eu/en/

78. Al-Hadithi Al and Hilal NN, The possibility of enhancing some properties of self-compacting concrete by adding waste plastic fibers. J Build Eng 8:20-28 (2016).

79. Jassim AK, Recycling of polyethylene waste to produce plastic cement. Procedia Manuf 8:635-642 (2017).

80. Saikia $\mathrm{N}$ and De Brito J, Use of plastic waste as aggregate in cement mortar and concrete preparation: a review. Construct Build Mater 34:385-401 (2012).

81. RFA. Pocket Guide to Ethanol 2017. (2017).

82. Gupta A and Verma JP, Sustainable bio-ethanol production from agro-residues: a review. Renew Sustain Energy Rev 41:550-567 (2015).

83. MAPA. Plano Agrícola e Pecuário 2018/2019. (2018).

84. Spallina V, Velarde IC, Jimenez JAM, Godini HR, Gallucci F and van Sint Annaland M, Techno-economic assessment of different routes for olefins production through the oxidative coupling of methane (OCM): advances in benchmark technologies. Energ Conver Manage 154:244-261 (2017). accessed date April 5th, 2020.

85. European Commission, Plastic waste: ecological and human health impacts. Sci Environ Foreign Policy:1-37 (2011).

86. UN Environment. Global Waste Management Outlook. (2015). https://doi.org/10.18356/765baec0-en

87. Woods JS, Veltman K, Huijbregts MAJ, Verones F and Hertwich EG, Towards a meaningful assessment of marine 
ecological impacts in life cycle assessment (LCA). Environ Int 89-90:48-61 (2016).

88. ISO. Greenhouse gases-Carbon footprint of productsRequirements and guidelines for quantification. (2018). Available: https://www.iso.org/standard/71206.html

89. Nimana B, Verma A, di Lullo G, Rahman MM, Canter CE, Olateju B et al., Life cycle analysis of bitumen transportation to refineries by rail and pipeline. Environ Sci Technol 51:680-691 (2017).

90. IPCC. Mobile combustion. Guidelines for National Greenhouse Gas Inventories (2006).

91. Seabra, J., Macedo, I., Chum, H., Faroni, C. \& Sarto, C. Life cycle assessment of Brazilian sugarcane products: GHG emissions and energy use. 519-532 (2011). https://doi. org/10.1002/bbb. accessed date May 7th, 2020.

92. Walter Arnaldo, Galdos Marcelo Valadares, Scarpare Fabio Vale, Leal Manoel Regis Lima Verde, Seabra Joaquim Eugênio Abel, Cunha Marcelo Pereira da, et al., Brazilian sugarcane ethanol: developments so far and challenges for the future. Adv Bioenergy Sustain Chall 00:373-394 (2015).

93. Platts. Petrochemical industry conversions. (2017).

94. Boulamanti, A. \& Moya, J. A. Energy efficiency and GHG emissions: prospective scenarios for the chemical and petrochemical industry. European Union (2017). https://doi. org/10.2760/20486

95. MCTIC. Método da análise de despacho. (2017). Available: https://www.mctic.gov.br/mctic/opencms/ciencia/SEPED/ clima/textogeral/emissao_despacho.html.

96. Rossi V, Cleeve-Edwards N, Lundquist L, Schenker U, Dubois C, Humbert S et al., Life cycle assessment of endof-life options for two biodegradable packaging materials: sound application of the European waste hierarchy. J Clean Prod 86:132-145 (2015).

97. Rigamonti L, Niero M, Haupt M, Grosso M and Judl J, Recycling processes and quality of secondary materials: food for thought for waste-management-oriented life cycle assessment studies. Waste Manag 76:261-265 (2018).

98. Shonfield, P. LCA of management options for mixed waste plastics. Waste Resource Action Programme WRAP (2008). doi:1-81105-397-0

99. Indústria Brasileira de Árvores. Relatório 2017. (2017).

100. dos Santos MC et al., Inventário florestal utilizando técnicas de silvicultura de precisão em povoamentos de Eucalyptus grandis hill ex maiden. Floresta e Ambiente 24:24 (2017).

101. Angelkorte GB, Modelagem do Setor Agropecuário Dentro de Modelo de Análise Integrada Brasileiro. UFRJ (2019).

102. De Araujo HJB, Inventário florestal a $100 \%$ em pequenas áreas sob manejo florestal madeireiro. Acta Amaz 36:447464 (2006).

103. Oliveira JT d S, Hellmeister JC and Tomazello Filho M, Variação do teor de umidade e da densidade básica na madeira de sete espécies de eucalipto. Rev Árvore 29:115127 (2005).

104. Silveira LHC, Rezende AV and Vale AT d, Teor de umidade e densidade básica da madeira de nove espécies comerciais Amazônicas. Acta Amaz 43:179-184 (2013).

105. Sato Juliana Hiromi Sato1, Figueiredo Cícero Célio de, Marchão Robélio Leandro, Oliveira Alexsandra Duarte de, Vilela Lourival, Delvico Francisco Marcos et al., Understanding the relations between soil organic matter fractions and $\mathrm{N} 2 \mathrm{O}$ emissions in a long-term integrated crop-livestock system. Eur J Soil Sci 70:1183-1196 (2019). accessed date April 7th, 2020.

106. Salton JC, Kichel AN, Arantes M, Kruker JM and Zimmer AH, et al. Sistema São Mateus - Sistema de Integração Lavoura-
Pecuária para a região do Bolsão Sul-Mato-Grossense. Embrapa (2013). accessed date April 5th, 2020.

107. Köberle, A. de C. Implementation of land use in an energy system model to study the long-term impacts of bioenergy in Brazil and its sensitivity to the choice of agricultural grennhouse gas emission factors. Ph.D. thesis, Univ Fed do Rio Janeiro, 2018. 35149 (2018).

108. Rochedo PRR, Soares-Filho B, Schaeffer R, Viola E, Szklo A, Lucena AFP et al., The threat of political bargaining to climate mitigation in Brazil. Nat Clim Chang 8:695-698 (2018).

109. Governo de São Paulo. Madeira legal Vs. Madeira ilegal. (2019). Available: https://www.infraestruturameioambiente. sp.gov.br/madeiralegal/madeira-legal-vs-madeira-ilegal/.

110. Imazon. Sistema de Monitoramento da Exploração Madeireira (Simex): Estado do Pará 2016-2017. (2019). Available: https://imazon.org.br/publicacoes/sistema-demonitoramento-da-exploracao-madeireira-simex-estadodo-para-2016-2017/.

111. Costa d and de BL, C. Quantificação das Emissões de CO2 Geradas na produção de materiais utilizados na construção civil no Brasil, in Universidade Federal do Rio de Janeiro. COPPE/ Federal University of Rio de Janeiro: Master thesis; (2012).

112. MCTIC. Modelagem Setorial De Opções De Baixo Carbono Para O Setor De Cimento. (2017).

113. FICCI. Sustainable infrastructure with plastics. 3rd Natl Conf 1-48 (2017).

114. Prasad $M$ and Jaysawal $D$, Use of plastic waste in concrete. Int Res J Eng Technol 04:1914-1917 (2017).

115. Sulyman M, Haponiuk J and Formela K, Utilization of recycled polyethylene terephthalate (PET) in engineering materials: a review. Int J Environ Sci Dev 7:100-108 (2016).

116. Doran $D$ and Cather $B$, Construction materials reference book. Construct Build Mater 7 London: Routledge; (2014).

117. Xue M, Study and application of plastic construction materials. Appl Mech Mater 99-100:1117-1120 (2011).

118. The Constructor. Density of Construction Materials in Kg/ m3 and Lb/ft3. (2019) https://theconstructor.org/building/ density-construction-materials/13531/ [7 July 2020].

119. Ecoinvent Centre. Ecoinvent data v3.2 (2015).

120. IPCC. Stationary combustion. (2006).

121. PlasticsEurope. Eco-profiles and Environmental Product Declarations of the European Plastics Manufacturers: Benzene, Toluene and Xylenes (Aromatics, BTX) (2013).

122. CPME. Purified terephthalic acid (PTA) CPME February 2016. Comm PET Manufactures in Europe 1-32 (2016).

123. CPME. Polyethylene Terephthalate (PET): Bottle Grade. 29 (2017).

124. Shen L, Nieuwlaar E, Worrell E and Patel MK, Life cycle energy and GHG emissions of PET recycling: changeoriented effects. Int J Life Cycle Assess 16:522-536 (2011).

125. PlasticsEurope. European plastics industry. Pentane 1-17 (2005).

126. PlasticsEurope. Expandable Polystyrene (EPS). 1-31 (2015).

127. Braskem. Polietileno verde I'm green ${ }^{\mathrm{TM}}$ (PE verde I'm green $^{\mathrm{TM}}$ ). (2020).

128. Oliveira, C. C. N. de, Angelkorte, G. B., Rochedo, P. R. R., \& Szklo, A. The role of biomaterials for the energy transition from the lens of a national integrated assessment model. (Forthcoming).

129. Comaniţ̌̆, E. D., Ghinea C, Ro?ca1 M, Simion I. M., Petraru M, \& Gavrilescu M, Environmental impacts of polyvinyl chloride (PVC) production process. $2015 \mathrm{E}$-Health Bioengineering Conference EHB 2015 2012, 5-8 (2016).

130. Boucher Julien, Billard Guillaume, Simeone Eleonora, Sousa Joao Gland, Switzerland: IUCN; (2020). https://doi.org/10.2305/ IUCN.CH.2020.01.en. accessed date May 18th, 2020 


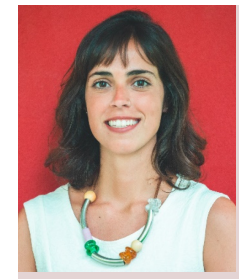

\section{Camilla C. N. de Oliveira}

Camilla C. N. de Oliveira is a chemical engineer and holds a $\mathrm{PhD}$ in energy planning from the Federal University of Rio de Janeiro (COPPE/UFRJ). Her research interests focus on energy and material transition scenarios, climate change, and energy system analysis.

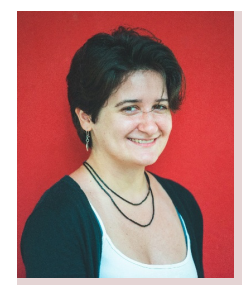

\section{Marianne Z. Zotin}

Marianne Zotin is a researcher and doctoral student in energy planning at COPPE/UFRJ. She holds a bachelor's degree in chemical engineering. Her research interests include renewable energy policy, energy transitions, and their material requirements.

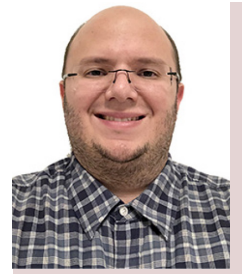

\section{Pedro R. R. Rochedo}

Pedro Rochedo is a professor at COPPE/UFRJ and holds a PhD in energy planning. He has a bachelor's degree in chemical engineering. His research interests include energy system analysis, integrated assessment modeling, and climate change.

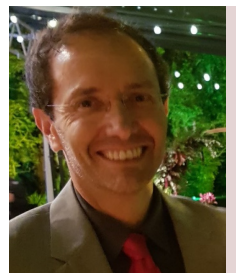

\section{Alexandre Szklo}

Alexandre Szklo is an associate professor of the Energy Planning Program of COPPE at the Federal University of Rio de Janeiro (UFRJ). He obtained his PhD from COPPE/ UFRJ and is a chemical engineer. He is the author of numerous books and papers in scientific journals, and has supervised more than 120 doctoral theses and master's dissertations. 